v. 8, n.4

Vitória-ES, Oct. - Dec. 2011.

p. 89-117 ISSN 1808-2386 DOI: http://dx.doi.org/10.15728/bbr.2011.8.4.5

\title{
Regulation, diversification and investments abroad - impacts on the efficiency of investment management by Brazilian pension funds in light of portfolio theory
}

\author{
Luiz da Penha Souza da Silva ${ }^{\dagger}$ \\ Fundação Chesf de Assistência e Seguridade Social \\ Marcos Roberto Gois de Oliveira ${ }^{\Omega}$ \\ Universidade Federal de Pernambuco (UFPE)
}

\begin{abstract}
This article investigates, under the prism of portfolio theory, the effects of diversification of assets by Brazilian pension funds under four possible interest rate scenarios as well as identifies the implications for more efficient allocation of assets, including through possible investment abroad, of the limitations imposed by current regulations. The results of the simulations show that the imposition of allocation limits not only restricts the efficient frontier but also shifts it to the right. Therefore, diversification beyond the regulatory limits would improve the efficiency of asset allocation (reducing the risk), an effect that would be accentuated with the inclusion of foreign investments. Finally, the article provides evidence, from a technical standpoint, that Brazilian pension funds can increase their efficiency in allocating resources under any scenario, especially one of stability, and that with a real interest rate of around $4 \%$ a year it is essential to allow more investment flexibility, including investment in foreign assets.
\end{abstract}

Key words: Efficient frontier; portfolio theory of Markowitz; foreign investments; Brazilian pension funds.

${ }^{\dagger}$ Masters in economics from Pernambuco Federal University (UFPE). Institution: Fundação Chesf de Assistência e Seguridade Social. Address: Rua do Paissandu, 58 - Boa Vista, Recife - PE - Brazil CEP: 50070- 200 E-mail: luizdapenha@ fachesf.com.br Telephone: (81) 99715370

\footnotetext{
$\Omega$ Ph.D. in economics from Pernambuco Federal University (UFPE). Institution: Pernambuco Federal University (UFPE). Address: Av. dos Economistas, s/n - Cidade Universitária, Recife - PE Brazil - CEP: 50670-901 E-mail: mrgois@ hotmail.com

Telephone: (81) 21268878
}

Note from the Editor: This article was accepted by Antonio Lopo Martinez.

This work is licensed under a Creative Commons Attribution-Noncommercial-Share Alike 3.0 Unported License 


\section{INTRODUCTION}

Brazilian pension funds have traditionally allocated the majority of their resources in federal bonds, with only a small portion (around $20 \%$ on average) invested in stocks with high liquidity traded on the São Paulo Stock Exchange (BM\&FBovespa). This allocation strategy concentrated in Brazilian government debt results from the high interest rates paid on this debt and the relatively low risk. The results have been satisfactory, at least from the standpoint of the return achieved.

Although the benchmark interest rate (SELIC rate) in Brazil is one of the highest in the world, the historical trend of the series in recent years shows a clear trend for this rate to decline.

The SELIC rate is the main monetary policy instrument used to control inflation. The Monetary Policy Committee (COPOM) of the Brazilian Central Bank raises or lowers this rate depending on economic indicators and inflation expectations. The target for the SELIC rate established by the Committee, at its meeting on July 22, 2009, was $8.75 \%$ a year. The market expectations, published by the Central Bank in its Focus survey of April 9, 2010, indicated an increase of to $9.25 \%$ at the next COPOM meeting. The chart below shows the market expectations published by the Focus report for the SELIC rate and inflation expectations.

\begin{tabular}{|l|c|c|c|c|c|}
\hline INDICATOR & $\mathbf{2 0 1 0}$ & $\mathbf{2 0 1 1}$ & $\mathbf{2 0 1 2}$ & $\mathbf{2 0 1 3}$ & $\mathbf{2 0 1 4}$ \\
\hline SELIC (\% pa) & 11.25 & 10.75 & 10.00 & 9.75 & 9.00 \\
\hline IGP-M (\% pa) & 9.16 & 5.50 & 5.00 & 4.50 & 4.40 \\
\hline IPCA (\% pa) & 5.53 & 4.80 & 4.50 & 4.50 & 4.50 \\
\hline
\end{tabular}

Chart 1: Inflation indicators - expectations

Source: Banco Central do Brasil (2009).

The yield on federal bonds of various types is directly related to the SELIC rate. In May 2007 the real interest rate on long-term federal bonds ${ }^{i}$ reached $5.8 \%$ a year, with a tendency to decline, causing great concern to pension fund portfolio managers because of the difficulty of attaining a return of $6 \%$ a year as required by the forecast actuarial calculations.

As a result of the global financial crisis, which hit Brazil in the last quarter of 2008, this rate went back up to above $6 \%$ a year. But the long-term expectation is that this rate will go down again and stabilize below $6 \%$ a year in real terms, making it increasingly urgent to start a process of reallocating the resources managed by Brazilian pension funds. The 
decisions on how to react to this huge challenge involves some questions that need to be clarified to pension fund participants and managers.

Among these challenges are the tradeoff between risk and return and the formulation of new regulations for Brazilian pension funds. The investment policy of a private pension fund must be within the risk limits necessary to meet the actuarial commitments. The portfolio manager cannot aim only to achieve absolute maximum return without considering the risks of the positions taken. The risks must be compatible with the returns, so as to maximize the yield while still limiting the risks to permissible levels.

The regulations covering investment of the resources entrusted to pension funds vary from country to country, ranging from the "prudent man rule" to much stricter rules that impose limits, control systems and punishments for any deviations, such as those established in Brazili ${ }^{\mathrm{ii}}$.

In an attempt to contribute to this debate and to help resolve some issues with strictly technical elements, in this study we seek to answer the following questions:

i. Are resources being allocated efficiently from the standpoint of portfolio theory?

ii. Is there a need for more diversification of assets, including the possibility of foreign investments?

iii. Are the limits imposed by current regulations causing, or might they cause in the near future, any restriction on the efficient allocation of resources?

For this purpose, we utilized the well-established theory for construction of efficient frontiers, in the return versus risk plane, originally proposed by Markowitz (1952). Therefore, in the present article we investigate, in light of portfolio theory, the effects of diversification of assets on Brazilian pension funds under four possible real interest rate scenarios for Brazil, as well as identify the implications for more efficient allocation considering the limitations imposed by current regulations.

The approach utilized can be defined as a static allocation study, since our objective was not to propose any particular investment strategy ex-ante, but rather to evaluate the effects of diversification on the assets of pension funds. 


\section{THEORETICAL FRAMEWORK}

The way to allocate the assets held in a portfolio has been the subject of many discussions and increasingly sophisticated technical and academic studies, as touched on below.

Lopes \& Furtado (2006), citing Swensen (2000), presented a graph showing gains in the efficient frontier in the "expected return versus standard deviation" plane when investments in private equity funds were added to the traditional assets held by pension funds. They examined and discussed the inclusion of holdings in private equity, venture capital and mezzanine funds by private pension entities in Brazil and concluded that investing in these funds could present excellent opportunities for diversification.

In turn, Savoia \& Bellato (2007) investigated the effects of internationalizing the portfolios in the Brazilian capital market. They considered portfolios holding the assets in which Brazilian pension funds traditionally invest and those diversified with holdings tracking the indexes of 24 selected countries. According to the authors, the results obtained demonstrate that the restrictions imposed on Brazilian pension funds prevent the formation of portfolios with lower risk for a determined level of return and also the possibility of obtaining higher returns than by investments only in the domestic market.

Damião (2007) made a comparison of portfolios optimized according to the meanvariance criterion, formed by robust risk and return estimates, whose results were not statistically different when compared to the classic mean-variance estimates of the returns.

Lorenzo Filho (2008) showed evidence that institutional investors should create an optimal diversification of their portfolios, with exposure to traditional and alternative assets, in an attempt to minimize risks. Besides this, given the long investing horizon of pension funds, the allocation should be made in the strategic plane.

Cardoso (2009), employing a dynamic asset allocation model where the risk was represented by the value-at-risk and whose risky asset was a theoretical portfolio of stocks tracking the Ibovespa (BM\&FBovespa index), with the corresponding risk-free rate of return being the IMA-B yield (federal bonds indexed to the IPCA), showed that dynamic allocation would face difficulties in reallocation of portfolios in response to the frequent change in the behavior of financial series.

Besides the examples mentioned above, there are various other works on efficient frontiers showing the gains that could be obtained by the inclusion of certain classes of assets 
in investment portfolios. However, we did not identify any article that has examined the allocation of investments in traditional and non-traditional assets, including international assets aimed at institutional investors, by Brazilian pension funds, considering various scenarios, among them one of a stable real interest rate of $4 \%$ a year.

\subsection{EFFICIENT PORTFOLIOTHEORY}

According to Markowitz (1952), the portfolio selection process can be divided into two stages: estimation of the expected future performance of the available assets and choice of the portfolio. The theory of Markowitz starts from the second stage, i.e., it is based on the assumption that the return and the respective variances are known and the investor considers an asset's expected return as something desirable and the variance of this return as something undesirable.

The portfolio with minimum variance according to the mean-variance theory established by Markowitz (1952) has a composition given by solving the following operational research problem:

$$
\begin{gathered}
\min \left\{V=\sum_{i=1}^{N} \sum_{j=1}^{N} X_{i} X_{j} \sigma_{i j}\right\} \\
\text { Sujeito } a \quad E=\sum_{i=1}^{N} X_{i} \mu_{i} \\
\sum_{i=1}^{N} X_{i}=1 \quad \text { para } \quad X_{i} \geq 0 ; \forall i,
\end{gathered}
$$

Where the vector $\mathbf{X}$ represents portfolio, $\boldsymbol{\mu}$ is the vector of the mean returns and $\boldsymbol{\sigma}$ is the vector of the standard deviation of the returns.

\subsection{ASSET CLASSES}

According to Sharpe (1992), an asset class should be composed of a set of assets, and preferably the asset classes should be mutually exclusive, exhaustive and relevant.

Individual assets and investment funds, the targets of allocation by investors, in general can be segregated into sets that present common characteristics, to the extent possible in line with the requirements of Sharpe (1992), whether in relation to the assets or the portfolio management strategies. In the present work, we consider these sets of assets or investment funds to be "asset classes". 
In some situations, these asset classes are represented by indexes published daily. In others, these indexes do not exist, so there is a need to assume some premise to implement the models.

\subsubsection{Private equity/venture capital funds as an asset class}

One of the sources of funding for investment in the real economy, either in companies or in specific projects, is private equity and venture capital funds. These funds are vehicles that take relevant stakes in the shares (and sometimes the bonds) issued by companies, with the aim of holding these stakes for a determined period and then divesting them. Their managers generally exercise some control over the portfolio companies by electing board members and/or executives.

These funds have quite different characteristics than those of other mutual funds and other classes of assets normally considered in the mean-variance portfolio models. Because of their low liquidity, it is hard to price and calculate the volatility of these funds.

Lamm (2001) used a series of the internal rates of return of private equity funds to calculate the standard deviation and correlations between the returns of these funds and those of other asset classes with similar allocation of resources according to the mean-variance criterion. He also presented sensitivity analysis of the effects of changes in the return of the assets under allocation.

\subsubsection{Foreign investment}

Investors in developed countries have long allocated resources to other countries, especially emerging countries where higher yields can be obtained compared to those in developed markets.

In Brazil, until September 23, 2009 the National Monetary Council (CMN), the entity that regulates the investments of private pension funds, only allowed these funds to invest $3 \%$ of their resources in investment funds that in turn invest in foreign assets (pursuant to CMN Resolution 3,456 of June 1, 2007). This limit was raised to $10 \%$ by CMN Resolution 3,792 of September 24, 2009, allowing such investments directly in securities of foreign companies admitted for trading in the Brazilian market and in investment funds with foreign investments authorized to operate by the Brazilian Securities Commission (CVM).

With the increasing globalization of the financial and capital markets, associated with the declining trend of the real interest rate in Brazil, local investors will naturally look for 
alternative investments, among them foreign investments. Over the long term, the internationalization of portfolios, especially by institutional investors, appears to be a natural tendency.

In line with this tendency, various institutions specialized in resource management and allocation in the international market already have set up commercial departments in Brazil and are making strong efforts to prospect for clients. Some examples are Barclays Global Investors, Credit Suisse, Goldman Sachs and Schroders, among others.

Despite the potential difficulties related to exchange rate, political and other risks, empirical evidence shows the advantages of allocating resources abroad. The underlying principle of these advantages is the beneficial effect of diversification.

\section{METHODOLOGY}

\subsection{DATA UTILIZED IN THE MODEL}

\subsubsection{Data on pension fund portfolios}

Due to the secrecy that is naturally maintained by pension funds about the assets managed by them, public information is not sufficient to determine with any precision an average allocation by class of assets representative of the industry. Therefore, we defined the portfolios to be tested based on suppositions made from the available information.

According to the Secretariat of Complementary Social Security (SPC, 2008), the total amount of assets under management by the 371 private pension funds active in Brazil in December 2008 was approximately R $\$ 417.5$ billion. These resources were distributed in the following investment segments defined by CMN Resolution 3,456/2007:

$\checkmark \quad$ Fixed income segment: $66.3 \%$;

$\checkmark \quad$ Variable income segment: $28.0 \%$;

$\checkmark \quad$ Real estate segment: $3.1 \%$;

$\checkmark \quad$ Transactions with participants segment: $2.6 \%$.

Further according to the SPC (2008), the net assets of the 10 largest Brazilian pension funds in December 2008 was roughly R \$ 256 billion. The largest of these funds is Caixa de Previdência dos Funcionários do Banco do Brasil - PREVI (the pension fund of Banco do Brasil's employees), with total assets of about R\$ 116 billion, representing $27.8 \%$ of the industry total. 
Table 1 shows the amounts and breakdown of the allocation of Brazilian pension funds in December 2008, deduced by us from the available information.

Table 1 - Estimate of the allocation of assets by Brazilian pension funds

\begin{tabular}{|c|c|c|c|c|c|c|}
\hline ASSET CLASSES & $\begin{array}{c}\text { All } \\
\text { Pension } \\
\text { Funds }\end{array}$ & $\begin{array}{c}\% \text { of the } \\
\text { Total }\end{array}$ & PREVI ${ }^{1}$ & $\begin{array}{c}\% \text { of the } \\
\text { Total } \\
\text { PREVI }\end{array}$ & $\begin{array}{c}\text { Pension } \\
\text { Funds } \\
\text { without } \\
\text { PREVI }\end{array}$ & $\begin{array}{c}\% \text { of the } \\
\text { Total w/o } \\
\text { PREVI }\end{array}$ \\
\hline $\begin{array}{l}\text { IRFM } \\
\end{array}$ & 21.6 & $5 \%$ & 4 & $3 \%$ & 17.6 & $6 \%$ \\
\hline IMA-B & 103.8 & $25 \%$ & 18 & $15 \%$ & 85.8 & $29 \%$ \\
\hline IMA-C & 39.9 & $10 \%$ & 7 & $6 \%$ & 32.9 & $11 \%$ \\
\hline IMA-S & 47.9 & $11 \%$ & 9 & $8 \%$ & 38.9 & $13 \%$ \\
\hline Private Credit & 43.6 & $10 \%$ & 1.6 & $1 \%$ & 42.0 & $14 \%$ \\
\hline Shares & 110 & $26 \%$ & 70.1 & $60 \%$ & 39.9 & $13 \%$ \\
\hline Real Estate & 12.0 & $3 \%$ & 3.2 & $3 \%$ & 8.758 & $3 \%$ \\
\hline Loans and Financings & 10.7 & $3 \%$ & 3.2 & $3 \%$ & 7.5 & $2 \%$ \\
\hline Real Estate Investment Funds - FII & 0.8 & $0.2 \%$ & 0.1 & $0.1 \%$ & 0.7 & $0.2 \%$ \\
\hline $\begin{array}{l}\text { Receivables Investment Funds - FIDC } \\
\text { Private Equity/Venture Capital Funds- }\end{array}$ & 7.4 & $1.8 \%$ & 0.0 & $0.0 \%$ & 7.4 & $2 \%$ \\
\hline FIP (PE/HC) & $\begin{array}{c}2.2 \\
17.1\end{array}$ & $\begin{array}{l}1 \% \\
4 \%\end{array}$ & $\begin{array}{c}0.1 \\
0\end{array}$ & $\begin{array}{l}0 \% \\
0 \%\end{array}$ & $\begin{array}{c}2.1 \\
17.1\end{array}$ & $\begin{array}{l}1 \% \\
6 \%\end{array}$ \\
\hline TOTAL & 417 & $100 \%$ & 116 & $100 \%$ & 300.7 & $100 \%$ \\
\hline
\end{tabular}

${ }^{1}$ Amounts estimated by the authors based on the following sources: Informe Estatístico SPC December 2008; Presentation of SPC at the XIV EPINNE - May 2009; Revista Investidor Institucional - Ed. 191 - May 2008; Annual Report of PREVI 2008.

Source: Prepared by the authors based on SPC (2008), SPC (2009), ABRAPP, Revista Investidor Institucional Ed. 191 - May 2008 and PREVI (2009).

In turn, Table 2 presents the allocations of the current hypothetical portfolios and the investment policy (deduced from the available information) assumedly representing the average assets of Brazilian pension funds in December 2008, by segment and classes of assets.

Table 2 - Current hypothetical portfolios and investment policies for Brazilian pension funds

\begin{tabular}{|c|c|c|c|}
\hline \multirow[b]{2}{*}{ ASSET CLASSES } & \multicolumn{2}{|c|}{ Allocation (\% of the total) } & \multirow[b]{2}{*}{$\underset{\text { Limits }^{2}}{\text { Maximum }}$} \\
\hline & $\begin{array}{c}\text { Hypothetical } \\
\text { Portfolio }^{1}\end{array}$ & $\begin{array}{c}\text { Investment } \\
\text { Policy }\end{array}$ & \\
\hline FIXED INCOME & $78.1 \%$ & $50.0 \%$ & $100 \%$ \\
\hline IMA-B & $31.3 \%$ & $22.0 \%$ & $100 \%$ \\
\hline IMA-S & $14.7 \%$ & $3.0 \%$ & $100 \%$ \\
\hline IMA-C & $11.7 \%$ & $10.0 \%$ & $100 \%$ \\
\hline IRFM & $6.5 \%$ & $0.0 \%$ & $100 \%$ \\
\hline PRIVATE CREDIT - PC & $13.9 \%$ & $15.0 \%$ & $80 \%$ \\
\hline VARIABLE INCOME & $14.1 \%$ & $35.0 \%$ & $50 \%$ \\
\hline SHARES & $14.0 \%$ & $30.0 \%$ & $50 \%$ \\
\hline $\begin{array}{l}\text { PRIVATE EQUITY/VENTURE } \\
\text { CAPITAL FUNDS (PE/VC) }\end{array}$ & $0.1 \%$ & $5.0 \%$ & $20 \%$ \\
\hline OTHER ASSETS & $0.0 \%$ & $3 \%$ & $3 \%$ \\
\hline REAL ESTATE & $4.2 \%$ & $5.0 \%$ & $8 \%$ \\
\hline LOANS AND FINANCINGS & $3.6 \%$ & $10.0 \%$ & $15 \%$ \\
\hline TOTAL & $100.0 \%$ & $100.0 \%$ & \\
\hline
\end{tabular}

${ }^{1}$ Without PREVI according to the note in the previous chart: OTHERS was changed with the other asset classes;

${ }^{2}$ Established by CMN Resolution 3,456/2007

Source: Prepared by the authors based on SPC (2008), SPC (2009), ABRAPP, Revista Investidor Institucional Ed. 191 - May 2008 and PREVI (2009). 


\subsubsection{Choice of the domestic asset classes}

Initially we identified and researched the main classes of assets available in the Brazilian market that can be held by pension funds, according to National Monetary Council (CMN) Resolution 3,456/2007.

These classes and the respective indexes utilized to represent them are presented in Table 3:

Table 3 - Asset classes and their respective benchmarks

\begin{tabular}{lcc}
\hline \multicolumn{1}{c}{ ASSET CLASS } & $\begin{array}{c}\text { Index or value estimated to represent } \\
\text { the respective asset class }\end{array}$ & Source \\
\hline Federal Bonds (pre-fixed) & IRFM & ANDIMA \\
Federal Bonds (indexed to the IPCA) & IMA-B & ANDIMA \\
Federal Bonds (indexed to the IGP-M) & IMA-C & ANDIMA \\
Federal Bonds (post-fixed, except LFT-A & IMA-S & ANDIMA \\
and LFT-B) & IFM Risk Office & RISK OFFICE \\
Multimarket Funds & IFM-I Risk Office & RISK OFFICE \\
Institutional Multimarket Funds & LSI Risk Office & RISK OFFICE \\
Long-Short Funds & Leturn of the Credit Receivables Funds & ANBID \\
Private Credit Receivables Funds - PC & IBOVESPA & BM\&FBOVESPA \\
Liquid Shares & Private Equity Index Europe and & BLOOMBERG and \\
Private Equity/Venture Capital Funds & Cambridge Associates Private Equity & CAMBRIDGE \\
Real Estate & Index & ASSOCIATES \\
Loans and Financing to Participants - CA- & Return of the IGP-M & FGV \\
EFP & & \\
SFP & IPCA + 6\% per year & IBGE \\
\hline
\end{tabular}

Source: Prepared by the authors.

The Private Equity/Venture Capital asset class includes investments in these funds as well as in special purpose companies (SPCs) ${ }^{\mathrm{iii}}$.

In doing this research, we analyzed two indexes of returns available in the market: the Private Equity Index Europe (PRIVEX), which represents the performance of the shares of private equity firms traded on international exchanges, and the Cambridge Associates Private Equity Index (CA PE), which represents the quarterly returns of the private equity industry in the United States. Because of the availability of a daily series of returns for the PRIVEX (Bloomburg Code PRIVEXPD), we considered this index in the simulations.

The "Real Estate" class, despite being one of the most traditional, does not have an index that can represent it. Therefore, since a good part of the resources allocated in this class of assets is invested in income property, we assumed the IGP-M (general market price index) series as representing the expected returns and risk of this class of assets (this index is generally used to adjust rents under lease agreements). 
We obtained the return and risk of the "Loans and Financings to Participants (CAEFP)" class of assets from the historic series of the consumer price index (IPCA) plus a spread of $6 \%$ a year. This is the minimum return permitted by the regulator to remunerate this asset class.

\subsubsection{Choice of the global asset classes}

An alternative to stock indexes frequently mentioned in the literature is international index funds ${ }^{\text {iv }}$ (exchange traded funds - ETFs). The justification for using exchange traded funds is that they issue shares that are traded in the market and whose returns are already net to the expenses inherent to an investment fund, while stock indexes are only indicators of the variation of prices and the derivatives linked to them are only traded in the future market.

Table 4 - International Exchange Traded Funds

\begin{tabular}{l|l}
\hline \multicolumn{2}{c}{ iShares Index Funds (International) } \\
\hline 1. iShares S\&P 500 & 13. iShares Dow Jones U.S. Financial Sector \\
2. iShares MSCI Emerging Markets & 14. iShares Dow Jones U.S. Real Estate \\
3. iShares MSCI Japan & 15. iShares MSCI Pacific ex-Japan \\
4. iShares FTSE/Xinhua China 25 & 16. iShares MSCI Mexico Investable Market \\
5. iShares MSCI United Kingdom & 17. iShares MSCI Germany \\
6. iShares MSCI ACWI & 18. iShares Lehman 20+ Year Treasury \\
7. iShares MSCI BRIC & 19. iShares Lehman 1-3 Year Treasury \\
8. iShares MSCI EAFE & 20. iShares Lehman Aggregate \\
9. iShares MSCI EMU & 21. iShares Lehman TIPS \\
10. iShares S\&P Latin America 40 & 22. iShares iBoxx \$ Investment Grade Corporate \\
11. iShares Russel 2000 & 23. iShares Lehman 7-10 Year Treasury \\
12. iShares Dow Jones U.S. Energy Sector & 24. iShares iBoxx \$ High Yield Corporate \\
\hline Source: Prepared by the authors.
\end{tabular}

We chose the most liquid of these funds managed by Barclays Global Investors (BGI), as shown in Table 4. These funds represent the performance of investments in the respective sectors and cover various international markets. The series of returns of these funds were provided by BGI and are available on Bloomberg ${ }^{\mathrm{v}}$.

\subsection{SCENARIOS}

We assumed the following scenarios to define the expectation of returns, risk and correlations in this work:

\footnotetext{
$\checkmark \quad$ Scenario I - 2004-2006 period;

$\checkmark \quad$ Scenario II - 2004-2007 period;

$\checkmark \quad$ Scenario III - 2004-2008 period;
} 
$\checkmark \quad$ Scenario IV - economic stability, with real interest rates of around $4 \%$ a year ${ }^{\mathrm{vi}}$ and variable income and alternative assets ${ }^{\mathrm{vii}}$ yielding an attractive premium over fixed income investments, even considering the respective volatility.

Scenarios I, II and III were represented by the series of monthly returns of the assets in the respective periods. Our main objective in including these scenarios was to evaluate the allocation of resources in the hypothesis in which the average market conditions over the medium and long term repeat what has happened in the past, so that the average return, risk and correlation can be represented by these series.

Scenario IV represents a situation over the medium and long horizon that the current forecasts of the Brazilian economy indicate is likely, and thus that pension funds must be in tune with due to the long-term characteristics inherent in their investment policies.

To determine the expected return related to Scenario IV, we made the following assumptions:

Pre-fixed federal bonds, represented by the IRFM, will present a real return in relation to the IPCA of $4 \%$ a year;

$\checkmark \quad$ The other domestic assets, under this scenario of stability and lower real interest rates, will maintain the relations existing in 2007 between the average returns of these assets and the IRFM;

The expected return for global assets will be those corresponding to the period from 2004 to 2007.

\subsection{METHODS AND PROCEDURES}

To simulate the efficient frontiers we used the PortfolioWorks version 3.1 software, applying the traditional methodology conceived by Markowitz (1952).

\subsubsection{Calculation of the return and volatility of the assets}

The asset prices refer to the closing price of each month of the historical return series and were deflated by the IPCA. We used this index because it represents the actuarial liability of the benefit plans managed by Brazilian pension funds. Therefore, the returns of the assets were calculated in terms of the real interest rate and must be compared directly with the interest rate of the actuarial target ${ }^{\text {viii }}$ of the mentioned plans (normally $6 \%$ per year). 
We expressed all the returns of the assets, including international ones, in Brazilian currency, the real (plural reais, or $\mathrm{R} \$$ ).

With the aim of assessing the influence of exchange rate variation on the returns, volatilities and correlations, and as a consequence on the efficient frontier, we converted the prices of international assets into reais considering the exchange rate of the closing day of each month and also assuming a fixed exchange rate. This assumption means making the percentage returns of the assets in dollars equal to those in reais. Therefore, the results are presented for situations of a floating and fixed exchange rate.

The volatilities were obtained directly from the series of returns by the standard deviation model. Given that the standard deviation estimator has some deficiencies, among them the fact it considers all the returns of the series with the same importance, according to Carmona (2008), we ran simulations considering the EWMA model with a decay factor of 0.94; also known as the RiskMetrics approach. We assumed the correlations were equal to those verified in the 2004-2007 historical series.

\subsubsection{The simulations}

We initially studied the effects of diversification on the efficient frontier by examining the allocation with the domestic assets permitted for Brazilian pension funds and then included the global assets.

When the global assets were included, we also investigated the effects of the exchange rate to assess the effect of exchange rate risk on the results.

We first ran the efficient frontier simulations without imposing limits on allocation of the assets. Then we imposed the limits established by CMN Resolution 3,456 of June 1, 2007 and assessed the implications of those limits. The maximum limits are shown below:

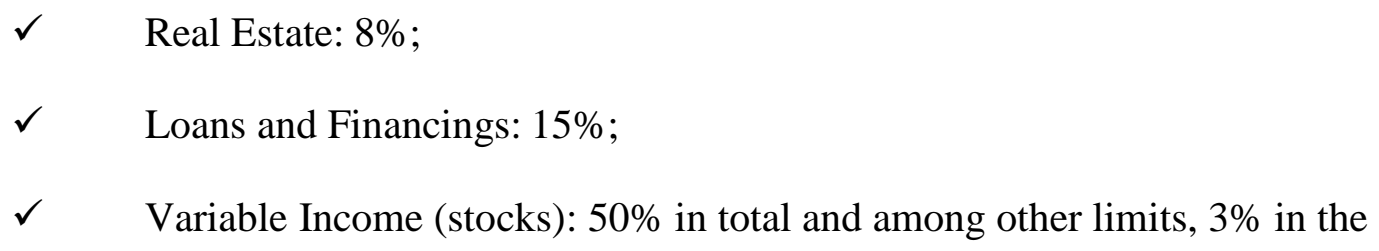
Other Assets portfolio - (investment funds without allocation restrictions: long-short, foreign investments, etc.)

Private Credit (PC): $80 \%$ for low-risk credit and 20\% for medium and highrisk credit. 
For each simulation we constructed 500 portfolios to compose the efficient frontier in the return $\mathrm{x}$ risk plane.

\section{PRESENTATION AND ANALYSIS OF THE RESULTS}

For the purposes of identifying, in the risk versus return plane, the ordered pair of the portfolio representing Brazilian pension funds, we considered all the assets of this portfolio to be present, as shown in Table 4 .

Regarding the contributions of each asset to improve the allocation efficiency, we considered the following criteria for inclusion/exclusion of assets in/from the model:

$\checkmark \quad$ Exclusion of assets that present expectations of negative return or high correlation (correlation greater than 0.70 for the period from 2004 to 2007);

$\checkmark \quad$ Inclusion of only one asset among those that present similar characteristics of return, volatility and correlation.

Therefore, considering the values of the returns, volatilities and correlations, we selected the following assets for the simulations:

I - Domestic assets: IMA-B, IMA-C, IMA-S, Ibovespa, IFM-I, LSI, credit receivables funds, real estate and loans.

II - International assets: IShares MSCI Emergent Markets; iShares S\&P Latin America 40; iShares Dow Jones U.S Energy Sector; iShares MSCI Pacific ex-Japan; and iShares MSCI México Investable Markets.

Table 5 shows the values of the real return and risk utilized in the simulations, for the respective classes of assets for each scenario.

The above table shows that for the great majority of the assets, the average monthly returns are very low in Scenario III, which includes the returns for 2008 in the series. This behavior brings the effects of the most recent global financial crisis on the return of the assets, showing the worsening of this crisis in 2008.

We should point out that the returns of the global assets were considered in U.S. dollars. In the simulations of the efficient frontiers we considered the returns in dollars and reais to assess the effects of exchange rate variation.

The mentioned table also shows that the domestic assets were affected much less by the crisis than the international assets. Therefore, Scenario III, which includes 2008 in the 
return series, was used in this study only to assess the influence of the most recent global financial crisis on the variables considered in the resource allocation model utilized.

Table 5 - Returns and volatilities by asset class and scenario

\begin{tabular}{|c|c|c|c|c|c|c|c|c|c|}
\hline \multirow[b]{2}{*}{ ASSETS } & \multicolumn{4}{|c|}{$\begin{array}{l}\text { EXPECTATION OF REAL } \\
\text { RETURN } \\
\text { (monthly) }\end{array}$} & \multicolumn{5}{|c|}{$\begin{array}{l}\text { EXPECTATION OF RISK } \\
\text { (STANDARD DEVIATION) }\end{array}$} \\
\hline & $\begin{array}{l}\text { Scenar } \\
\text { io I }\end{array}$ & $\begin{array}{l}\text { Scenar } \\
\text { io II }\end{array}$ & $\begin{array}{c}\text { Scenar } \\
\text { io III }\end{array}$ & $\begin{array}{l}\text { Scenar } \\
\text { io IV }\end{array}$ & $\begin{array}{l}\text { Scenar } \\
\text { io I }\end{array}$ & $\begin{array}{l}\text { Scenar } \\
\text { io II e } \\
\text { IV }\end{array}$ & $\begin{array}{l}\text { Scenar } \\
\text { io III }\end{array}$ & $\begin{array}{c}\text { EWM } \\
\mathbf{A}\end{array}$ & $\begin{array}{c}\text { Média } \\
\text { EWM } \\
\text { A }\end{array}$ \\
\hline IRFM & $0.92 \%$ & $0.81 \%$ & $0.77 \%$ & $0.33 \%$ & $0.61 \%$ & $0.65 \%$ & $0.93 \%$ & $0.25 \%$ & $0.92 \%$ \\
\hline IMA-B & $0.98 \%$ & $0.92 \%$ & $0.81 \%$ & $0.35 \%$ & $1.45 \%$ & $1.48 \%$ & $1.75 \%$ & $0.86 \%$ & $1.35 \%$ \\
\hline IMA-C & $0.86 \%$ & $1.02 \%$ & $0.95 \%$ & $0.29 \%$ & $1.30 \%$ & $1.49 \%$ & $1.38 \%$ & $0.27 \%$ & $1.34 \%$ \\
\hline IMA-S & $0.87 \%$ & $0.80 \%$ & $0.74 \%$ & $0.31 \%$ & $0.43 \%$ & $0.40 \%$ & $0.39 \%$ & $0.47 \%$ & $0.81 \%$ \\
\hline $\mathrm{PC}$ & $0.86 \%$ & $0.79 \%$ & $0.72 \%$ & $0.31 \%$ & $0.29 \%$ & $0.30 \%$ & $0.33 \%$ & $0.46 \%$ & $0.81 \%$ \\
\hline SHARES & $1.33 \%$ & $1.76 \%$ & $0.44 \%$ & $0.47 \%$ & $6.40 \%$ & $5.98 \%$ & $7.24 \%$ & $4.28 \%$ & $4.83 \%$ \\
\hline REAL ESTATE & $0.02 \%$ & $0.08 \%$ & $0.12 \%$ & $0.01 \%$ & $0.48 \%$ & $0.49 \%$ & $0.51 \%$ & $0.36 \%$ & $0.38 \%$ \\
\hline LOANS/FIN. & $0.57 \%$ & $0.59 \%$ & $0.58 \%$ & $0.22 \%$ & $0.26 \%$ & $0.23 \%$ & $0.22 \%$ & $0.63 \%$ & $0.58 \%$ \\
\hline IFM-I & $0.89 \%$ & $0.81 \%$ & $0.71 \%$ & $0.31 \%$ & $0.46 \%$ & $0.48 \%$ & $0.52 \%$ & $0.19 \%$ & $0.87 \%$ \\
\hline LSI & $1.21 \%$ & $1.05 \%$ & $0.82 \%$ & $0.43 \%$ & $3.06 \%$ & $2.69 \%$ & $2.52 \%$ & $0.70 \%$ & $1.70 \%$ \\
\hline $\mathrm{PE} / \mathrm{VC}$ & $1.06 \%$ & $0.49 \%$ & $-1.47 \%$ & $0.40 \%$ & $3.45 \%$ & $3.75 \%$ & $6.71 \%$ & $6.19 \%$ & $2.93 \%$ \\
\hline DOW JONES & $0.00 \%$ & $0.10 \%$ & $-0.74 \%$ & $0.10 \%$ & $1.96 \%$ & $2.26 \%$ & $3.40 \%$ & $4.34 \%$ & $1.87 \%$ \\
\hline NASDAQ & $0.09 \%$ & $0.16 \%$ & $-0.86 \%$ & $0.16 \%$ & $3.61 \%$ & $3.55 \%$ & $4.93 \%$ & $7.45 \%$ & $3.01 \%$ \\
\hline$S \& P$ & $0.21 \%$ & $0.21 \%$ & $-0.80 \%$ & $0.21 \%$ & $1.90 \%$ & $2.15 \%$ & $3.71 \%$ & $4.75 \%$ & $1.84 \%$ \\
\hline iShares S\&P 500 & $0.20 \%$ & $0.16 \%$ & $-0.93 \%$ & $0.16 \%$ & $2.06 \%$ & $2.81 \%$ & $4.34 \%$ & $6.44 \%$ & $2.17 \%$ \\
\hline $\begin{array}{l}\text { 1Dnares IVISCI Emerging } \\
\text { Markets }\end{array}$ & $1.40 \%$ & $1.75 \%$ & $-0.25 \%$ & $1.75 \%$ & $5.52 \%$ & $6.42 \%$ & $7.89 \%$ & $4.25 \%$ & $5.19 \%$ \\
\hline iShares MSCI Japan & $0.51 \%$ & $0.28 \%$ & $-0.72 \%$ & $0.28 \%$ & $4.90 \%$ & $4.63 \%$ & $5.22 \%$ & $7.00 \%$ & $3.58 \%$ \\
\hline $\begin{array}{l}\text { 1.snares Ivisc } 1 \text { united } \\
\text { Kingdom }\end{array}$ & $0.67 \%$ & $0.66 \%$ & $-0.98 \%$ & $0.66 \%$ & $2.77 \%$ & $3.63 \%$ & $5.36 \%$ & $2.85 \%$ & $2.88 \%$ \\
\hline IShares MSCI EAFE & $0.80 \%$ & $0.83 \%$ & $-0.73 \%$ & $0.83 \%$ & $2.96 \%$ & $3.61 \%$ & $5.34 \%$ & $2.89 \%$ & $2.94 \%$ \\
\hline IShares MSCI EMU & $0.93 \%$ & $1.05 \%$ & $-0.76 \%$ & $1.05 \%$ & $3.32 \%$ & $4.14 \%$ & $6.54 \%$ & $2.00 \%$ & $3.38 \%$ \\
\hline $\begin{array}{l}\text { isnares Sor Latın America } \\
\text { in }\end{array}$ & $2.34 \%$ & $2.66 \%$ & $0.60 \%$ & $2.66 \%$ & $6.22 \%$ & $7.37 \%$ & $9.12 \%$ & $4.70 \%$ & $6.35 \%$ \\
\hline IShares Russel 2000 & $0.50 \%$ & $0.26 \%$ & $-0.91 \%$ & $0.26 \%$ & $3.69 \%$ & $4.12 \%$ & $5.86 \%$ & $7.91 \%$ & $3.43 \%$ \\
\hline $\begin{array}{l}\text { ISnares ע J U.D. Energy } \\
\text { Sector }\end{array}$ & $1.56 \%$ & $1.64 \%$ & $0.39 \%$ & $1.64 \%$ & $6.14 \%$ & $6.16 \%$ & $6.97 \%$ & $2.88 \%$ & $5.39 \%$ \\
\hline $\begin{array}{l}\text { IShares D J U.S. Financial } \\
\text { Sector }\end{array}$ & $0.31 \%$ & $-0.21 \%$ & $-1.82 \%$ & $-0.21 \%$ & $2.64 \%$ & $3.99 \%$ & $6.79 \%$ & 15.14 & $2.91 \%$ \\
\hline IShares D J U.S. Real Estate & $0.96 \%$ & $0.35 \%$ & $-1.44 \%$ & $0.35 \%$ & $4.43 \%$ & $5.29 \%$ & $8.32 \%$ & & $4.27 \%$ \\
\hline IShares MSCI Pacific ex- & & & & & & & & & \\
\hline Ishanares MSCI Mex. & $0.94 \%$ & $1.35 \%$ & $-0.59 \%$ & $1.35 \%$ & $3.81 \%$ & $5.21 \%$ & $6.90 \%$ & $\begin{array}{l}4.21 \% \\
11.97\end{array}$ & $3.93 \%$ \\
\hline Investable Mark. & $2.48 \%$ & $2.10 \%$ & $0.35 \%$ & $2.10 \%$ & $5.99 \%$ & $6.70 \%$ & $8.17 \%$ & & $5.95 \%$ \\
\hline $\begin{array}{l}\text { iShares MSCI Germany } \\
\text { iShares Lehman 20+ Year }\end{array}$ & $0.85 \%$ & $1.23 \%$ & $-0.55 \%$ & $1.23 \%$ & $3.80 \%$ & $4.58 \%$ & $6.39 \%$ & $2.51 \%$ & $3.74 \%$ \\
\hline isheasures Lehman 1-3 Year & $-0.27 \%$ & $-0.28 \%$ & $0.00 \%$ & $-0.28 \%$ & $2.29 \%$ & $2.47 \%$ & $3.48 \%$ & $2.96 \%$ & $2.05 \%$ \\
\hline & $-0.52 \%$ & $-0.44 \%$ & $-0.39 \%$ & $-0.44 \%$ & $0.42 \%$ & $0.47 \%$ & $0.53 \%$ & $0.72 \%$ & $0.55 \%$ \\
\hline iShares Lehman Aggregate & $-0.48 \%$ & $-0.45 \%$ & $-0.47 \%$ & $-0.45 \%$ & $0.89 \%$ & $0.93 \%$ & $1.13 \%$ & $0.65 \%$ & $0.79 \%$ \\
\hline $\begin{array}{l}\text { iShares Lehman TIPS } \\
\text { iShares iBoxx \$ Invest. Grade }\end{array}$ & $-0.48 \%$ & $-0.36 \%$ & $-0.54 \%$ & $-0.36 \%$ & $1.48 \%$ & $1.59 \%$ & $2.02 \%$ & $3.01 \%$ & $1.29 \%$ \\
\hline Sprpares Lehman 7-10 Year & $-0.51 \%$ & $-0.51 \%$ & $-0.74 \%$ & $-0.51 \%$ & $1.32 \%$ & $1.27 \%$ & $2.19 \%$ & $0.06 \%$ & $1.04 \%$ \\
\hline Tre & $-0.48 \%$ & $-0.39 \%$ & $-0.22 \%$ & $-0.39 \%$ & $1.40 \%$ & $1.55 \%$ & $1.93 \%$ & $2.34 \%$ & $1.27 \%$ \\
\hline
\end{tabular}

Source: Prepared by the authors. 
We performed a detailed analysis of the expected risk for Scenario IV, which assumes a stable and low real interest rate. We initially applied the EWMA model considering the series of returns for 2004 to 2007 and found that some assets had a substantial distorting effect on the results, as can be seen in the penultimate column of Table 5, due to the high volatility of the last months of this period. To sidestep this distortion, we took the average of the volatilities obtained with the EWMA for each month. The result was satisfactory, but more conservatively, the simulations in this Scenario IV consider the volatility of the 20042007 period, which corresponds to Scenario II.

Table 5 also shows that in the fixed income class, the domestic assets have the same volatility as the global ones.

\subsection{HYPOTHETICAL PORTFOLIOS}

The portfolios that hypothetically represent the current one are those defined by the average investment policy for allocation of the Brazilian pension funds presented in Table 3. These portfolios were implemented using the PortfolioWorks software and the returns and risks correspond to those presented in Table 6 below.

Table 6 - Hypothetical portfolio returns and risks and investment policies

\begin{tabular}{|c|c|c|c|c|c|}
\hline & & SCENARIO I & SCENARIO II & SCENARIO III & SCENARIO IV \\
\hline \multirow{2}{*}{$\begin{array}{l}\text { Portfolio of } \\
\text { pension funds }\end{array}$} & Return & $0.92 \%$ & $0.96 \%$ & $0.71 \%$ & $0.33 \%$ \\
\hline & Std. Deviation & $1.13 \%$ & $1.16 \%$ & $1.46 \%$ & $1.16 \%$ \\
\hline \multirow{2}{*}{$\begin{array}{l}\text { Portfolio of the } \\
\text { investment policy }\end{array}$} & Return & $0.97 \%$ & $1.06 \%$ & $0.53 \%$ & $0.35 \%$ \\
\hline & Std. Deviation & $2.10 \%$ & $2.04 \%$ & $2.65 \%$ & $2.04 \%$ \\
\hline
\end{tabular}

Source: Prepared by the authors with data obtained from PortfolioWorks.

The reduction in the return of the portfolios and the elevation of the risks observed in Scenario III were caused by the depression of asset prices in this scenario due to the global financial crisis of 2008 .

With the exception of Scenario III, in all the other scenarios it can be seen that the investment policy seeks to obtain a higher expected return for the assets, and hence the risk also rises.

The reduction in the return of the portfolios in Scenario IV results from the assumptions of economic stability in this scenario, with real interest rates of around $4 \%$ a year. In this hypothesis, the expected return for the allocation defined in the investment policy ( $0.35 \%$ per month or $4.28 \%$ per year) is lower than the interest rate of the actuarial target of the majority of Brazilian pension funds, which is $6 \%$ a year. 
In the graphs that follow, the Current Holdings point corresponds to the current portfolio and the Policy point corresponds to the portfolio defined by the investment policy. The graphs also present the efficient frontiers for the assets in the portfolios of Brazilian pension funds in the four scenarios considered.

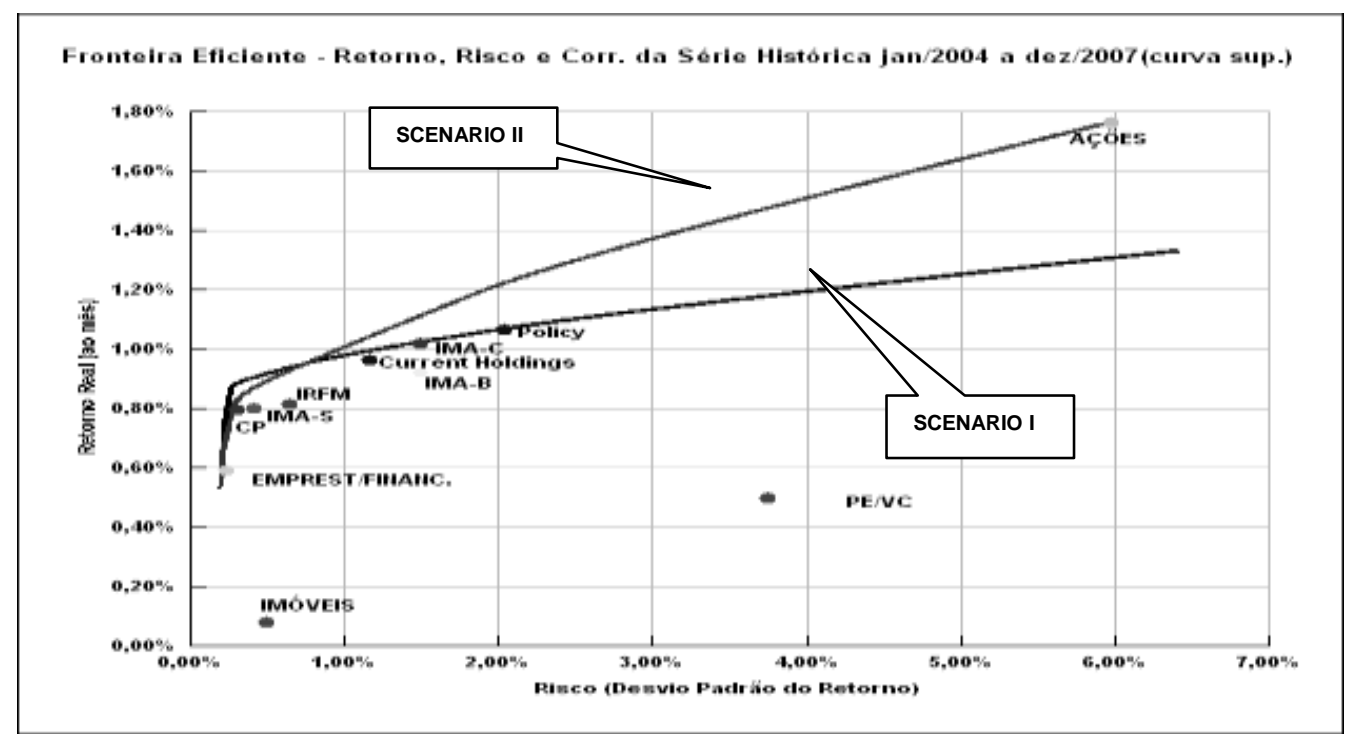

Figure 1 - Allocation of the hypothetical portfolio - Scenarios I/II Source: Output from PortfolioWorks.

These graphs show that it was possible to build efficient portfolios, for each scenario, with low risks and real returns greater than $0.5 \%$ per month, or $6 \%$ per year. This is the minimum yield required for the investments and corresponds to the maximum real interest rate permitted for the "actuarial target. This observation also applies to Scenario III, in which there was a large decline in asset prices due to the global financial crisis.

In Scenario IV, whose assumptions are economic stability and real interest rates around $4 \%$ a year, it is not possible to obtain a real return of $0.5 \%$ a month only with the current assets in the portfolios, even the efficient portfolios with higher risk.

Therefore, given that this scenario is increasingly probable, Brazilian pension fund managers need to revise the allocation of resources of their benefit plans and seek new investment alternatives. This new positioning will certainly bring higher risk to the portfolios, risk that will be a function of the new interest rate to be defined for the actuarial target. 


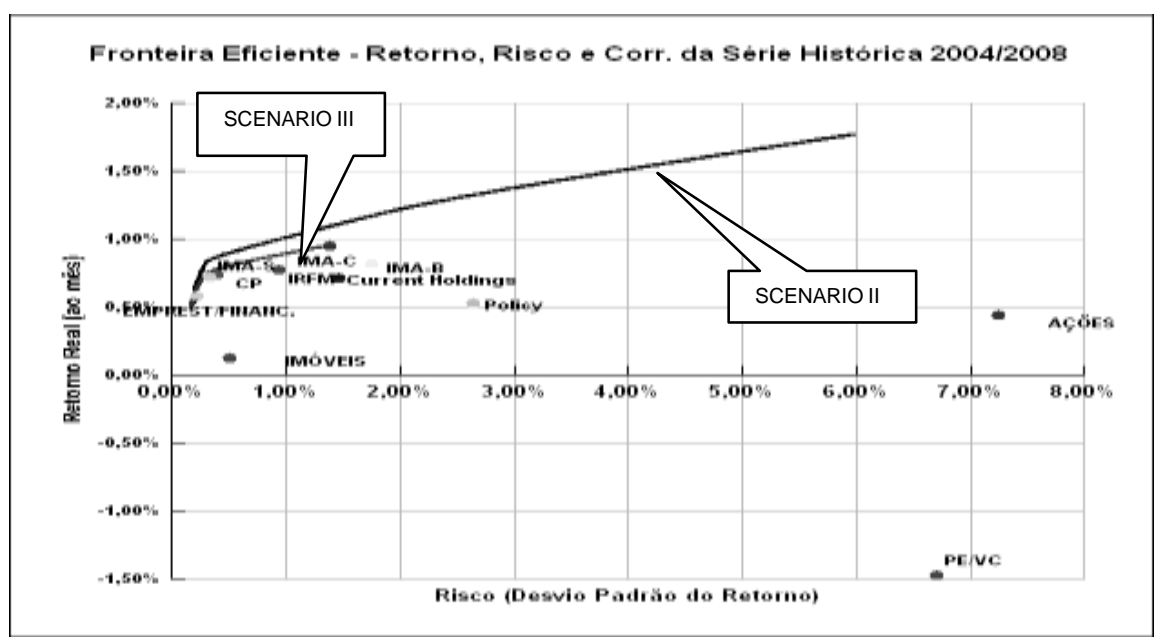

Figure 2 - Allocation of the hypothetical portfolio - Scenarios II/III Source: Output froml PortfolioWorks.

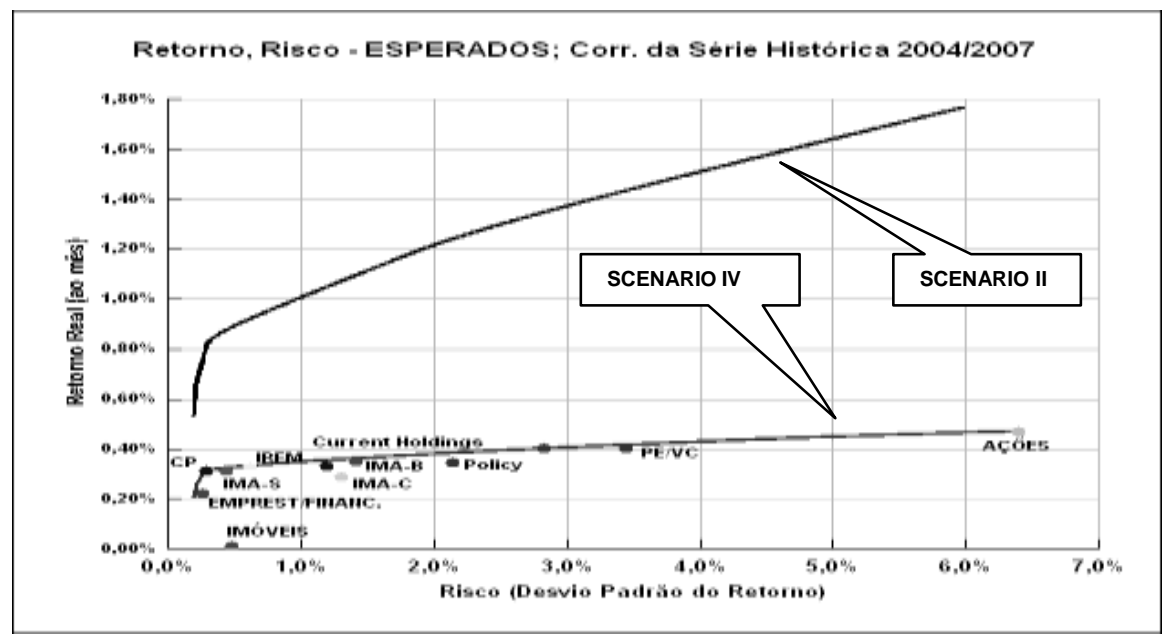

Figure 3 - Allocation of the hypothetical portfolio - Scenarios II/IV Source: Output from PortfolioWorks.

The graphs show that the points corresponding to Current Holdings and Policy are not located on the efficient frontier. Therefore, for both the current portfolio and that defined by the investment policy it is possible to obtain a portfolio with higher return for the same risk and one with the same return at lower risk, both located on the efficient frontier.

Table 7 below shows the values of the returns and risks for the current portfolio (Current Holdings) and the one defined by the investment policy (Policy) and the respective allocations of the optimized portfolios, in Scenarios I and II. 
Table 7 - Allocation of the hypothetical portfolio (current), investment policy and respective optimized portfolios (in \%)

\begin{tabular}{|c|c|c|c|c|c|c|c|c|c|c|c|c|}
\hline & \multicolumn{6}{|c|}{ SCENARIO I - 2004-2006 } & \multicolumn{6}{|c|}{ SCENARIO II - 2004-2007 } \\
\hline & $\begin{array}{c}\text { Current } \\
\text { Port. }\end{array}$ & $\begin{array}{c}\text { Opt. } \\
\text { Port. } \\
1\end{array}$ & $\begin{array}{c}\text { Opt. } \\
\text { Port. } \\
2\end{array}$ & Policy & $\begin{array}{c}\text { Opt. } \\
\text { Port. } \\
1\end{array}$ & $\begin{array}{c}\text { Opt. } \\
\text { Port. } \\
2\end{array}$ & $\begin{array}{c}\text { Current } \\
\text { Port. }\end{array}$ & $\begin{array}{c}\text { Opt. } \\
\text { Port. } \\
1\end{array}$ & $\begin{array}{c}\text { Opt. } \\
\text { Port. } \\
2\end{array}$ & Policy & $\begin{array}{c}\text { Opt. } \\
\text { Port. } \\
1\end{array}$ & $\begin{array}{c}\text { Opt. } \\
\text { Port. } \\
2\end{array}$ \\
\hline Returns & 0.92 & 0.93 & 0.99 & 0.97 & 0.97 & 1.07 & 0.96 & 0.96 & 1.04 & 1.06 & 1.06 & 1.22 \\
\hline Risks & & 0.58 & 1.13 & 2.10 & 0.90 & 2.10 & 1.16 & 0.78 & 1.16 & 2.04 & 1.25 & 2.04 \\
\hline \multicolumn{13}{|c|}{ COMPOSITION OF THE PORTFOLIOS } \\
\hline IRFM & 6.50 & 51.15 & 50.46 & 0.00 & 67.45 & 0.00 & 6.50 & 0.00 & 0.00 & 0.00 & 0.00 & 0.00 \\
\hline IMA-B & 31.30 & 14.03 & 38.68 & 22.00 & 25.47 & 74.05 & 31.30 & 0.00 & 0.00 & 22.00 & 0.00 & 0.00 \\
\hline IMA-C & 11.70 & 0.00 & 0.00 & 10.00 & 0.00 & 0.00 & 11.70 & 35.29 & 51.01 & 10.00 & 54.87 & 72.89 \\
\hline IMA-S & 14.40 & 0.00 & 0.00 & 3.00 & 0.00 & 0.00 & 14.40 & 0.00 & 0.00 & 3.00 & 0.00 & 0.00 \\
\hline $\mathrm{PC}$ & 13.90 & 31.54 & 0.00 & 15.00 & 0.00 & 0.00 & 13.90 & 55.99 & 35.59 & 15.00 & 30.59 & 0.00 \\
\hline SHARES & 14.00 & 3.28 & 10.86 & 30.00 & 7.08 & 25.95 & 14.00 & 8.72 & 13.40 & 30.00 & 14.55 & 27.11 \\
\hline $\mathrm{PE} / \mathrm{VC}$ & 0.50 & 0.00 & 0.00 & 5.00 & 0.00 & 0.00 & 0.50 & 0.00 & 0.00 & 5.00 & 0.00 & 0.00 \\
\hline REAL EST. & 4.10 & 0.00 & 0.00 & 5.00 & 0.00 & 0.00 & 4.10 & 0.00 & 0.00 & 5.00 & 0.00 & 0.00 \\
\hline $\begin{array}{l}\text { LOANS } \\
\text { /FINANC. }\end{array}$ & 3.60 & 0.00 & 0.00 & 10.00 & 0.00 & 0.00 & 3.60 & 0.00 & 0.00 & 10.00 & 0.00 & 0.00 \\
\hline TOTAL & 100 & 100 & 100 & 100 & 100 & 100 & 100 & 100 & 100 & 100 & 100 & 100 \\
\hline
\end{tabular}

For the four scenarios considered, a hypothetical portfolio that has the average composition of that assumed for the Brazilian pension funds would be operating outside the efficient frontier, and thus reallocation of its assets would bring greater efficiency. This same conclusion applies to an investment policy, also hypothetical, of this portfolio. Therefore, the simulations show that in a real case it is possible to make this type of evaluation and through this attain greater efficiency in managing pension fund investments.

\subsection{DIVERSIFICATION WITH DOMESTIC ASSETS}

Because of the analysis of the available data and the results of the simulations of the four scenarios presented in the previous item, we carried out the other steps of the study only with Scenarios II and IV, since those scenarios can be considered more realistic.

\subsubsection{Portfolios with the most common assets}

To evaluate the effect of diversification, we first traced out an efficient frontier only with the basic assets we assumed to be present in the portfolios of all Brazilian pension funds and then added the assets IMA-C + Private Credit (PC) + Shares. Figure 4 below shows the gain in efficiency with this new portfolio.

Given that the bonds represented by the IMA-C are no longer issued by the Brazilian Treasury and are little traded in the secondary market, investors cannot count on these assets to optimize their portfolios. So, we ran a simulation replacing the IMA-C with the IMA-B, which represents bonds that are issued more frequently by the Treasury and that attract great 
interest of pension funds, with good liquidity in the secondary market. For the above reasons, we did not consider the IMA-C in the other steps of the study.

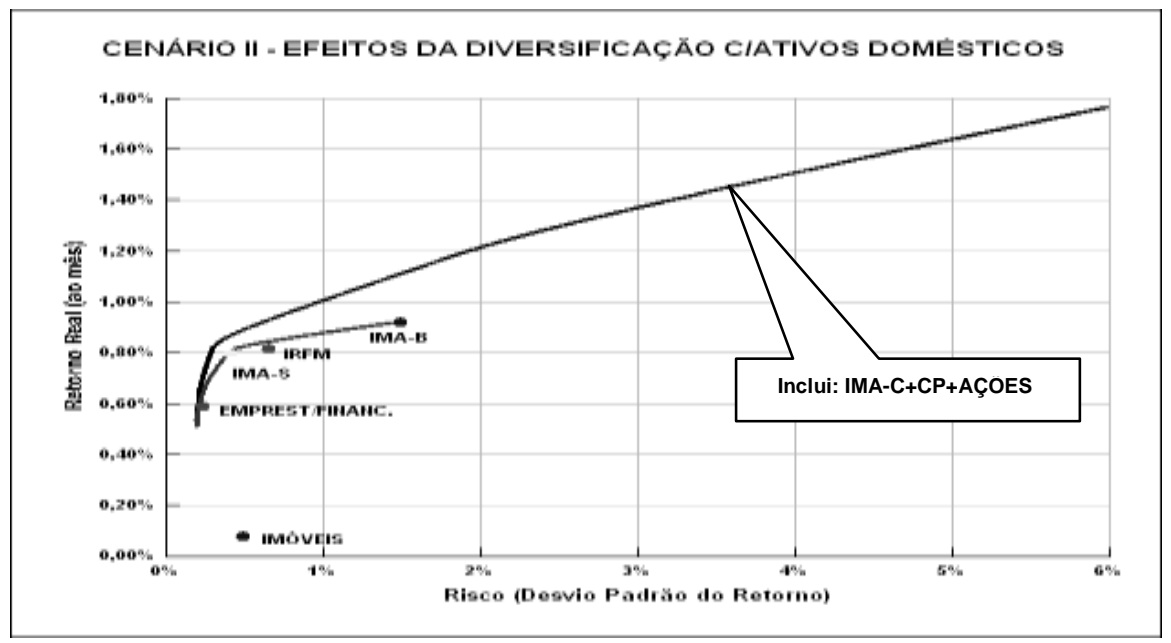

Figure 4 - Allocation of the assets in function of risk - Scenario II Source: Output from PortfolioWorks.

Figure 5 shows what occurs with the efficient frontier, where the loss of efficiency is evident with the substitution of the IMA-C by the IMA-B, in this Scenario II.

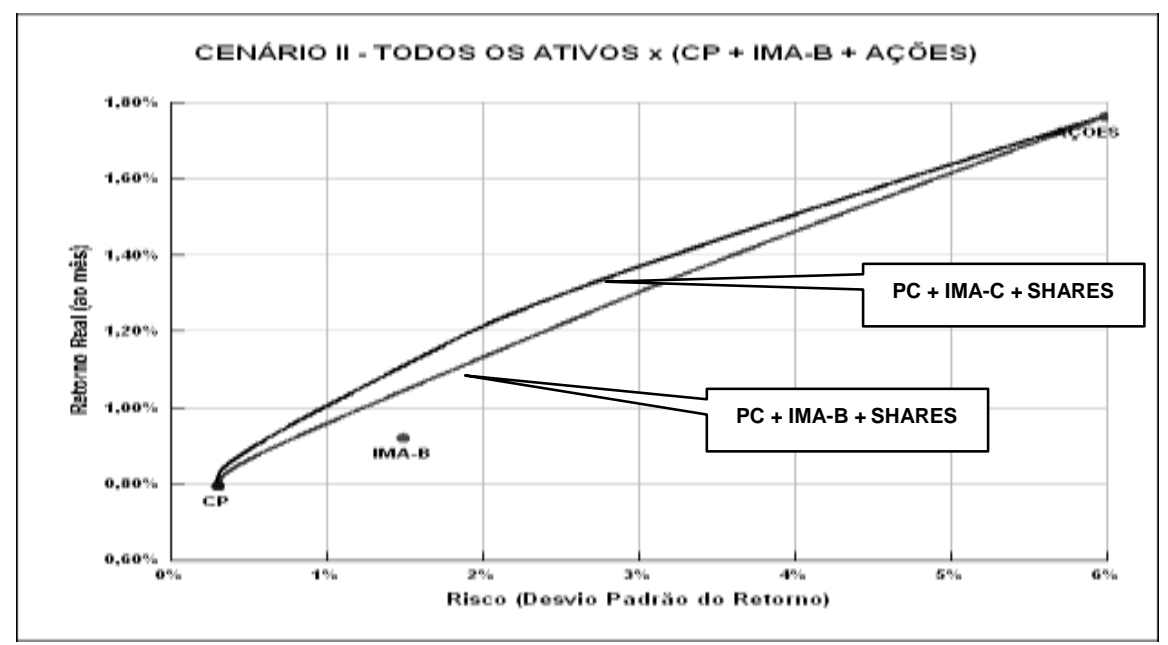

Figure 5 - Frontier with the IMA-C replaced by the IMA-B Source: Output from PortfolioWorks.

The results of the simulations for Scenario IV indicate, just as for Scenario II, that after disregarding assets represented by the IMA-C, the efficient frontier of the assets in the typical portfolio of Brazilian pension funds is mainly determined by the assets PC + IMA-B + Shares, except for the lowest risk range, as shown in the following figure. Therefore, this is the basic portfolio used in the next simulations for Scenario IV. 


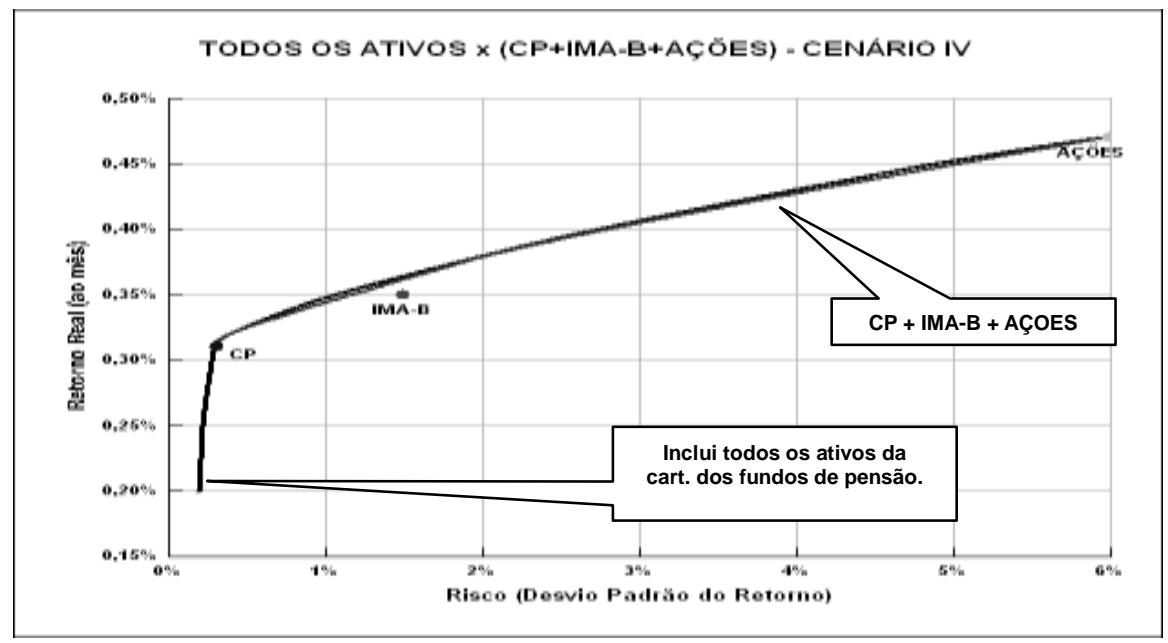

Figure 6 - Frontier with all the assets of Brazilian pension funds $x$ frontier only with (PC + IMA-B + Shares) - Scenario IV

Source: Output from PortfolioWorks.

\subsubsection{Portfolios with investments in multimarket and private equity funds}

Because of the previous results and considerations on the unavailability of the bonds that compose the IMA-C, we performed the simulations based on a basic portfolio composed of Private Credit + IMA-B + Shares.

\section{SCENARIO II}

We first added the IFM-I to the basic portfolio. This did not cause any change in the efficient frontier. On the other hand, the inclusion of the LSI (Long-Short Index) in the portfolio caused a significant gain in efficiency, as shown in Figure 7 below.

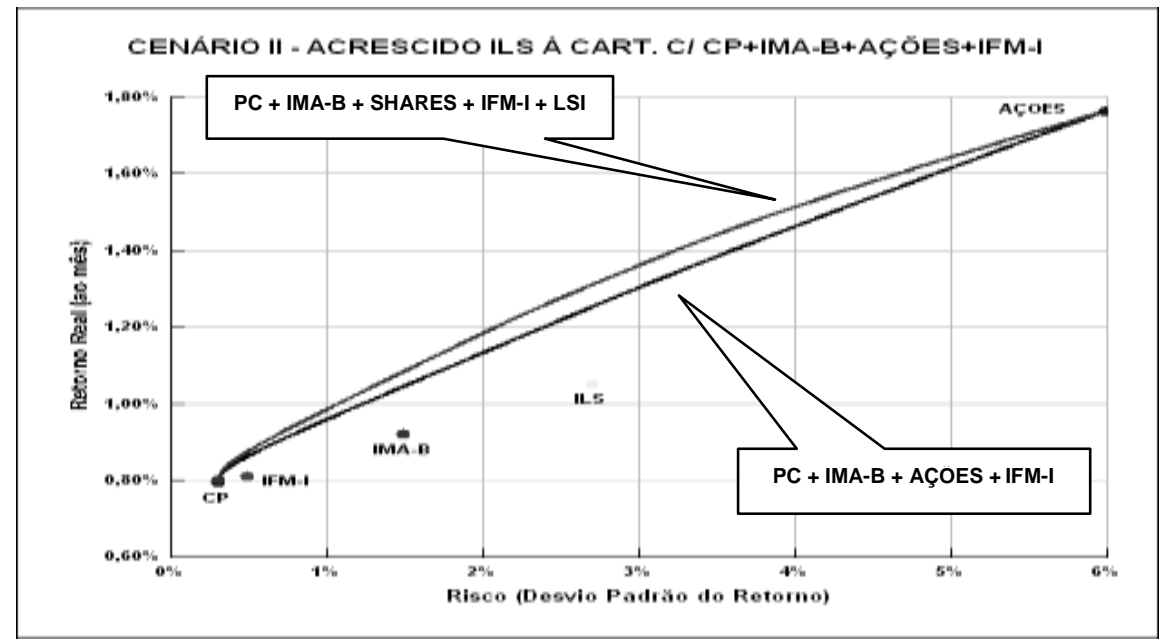

Figure 7 - Effects of the LSI (Long-Short Index)

Source: Output from PortfolioWorks. 
Given the basic portfolio, we simulated a new frontier including PE/VC and found that in Scenario II they do not contribute to improve the efficient frontier. We also assessed the composition of the portfolios and verified that $\mathrm{PE} / \mathrm{VC}$ investments were not allocated in any of the 500 simulated portfolios.

\section{SCENARIO IV}

Just as in Scenario II, the results of the simulations for Scenario IV show that the inclusion of IFM-I does not cause any change in the efficient frontier of the basic portfolio. In contrast, when adding the LSI to the basic portfolio in Scenario IV, the efficient frontier changed significantly, improving the portfolio's efficiency, as shown in Figure 8.

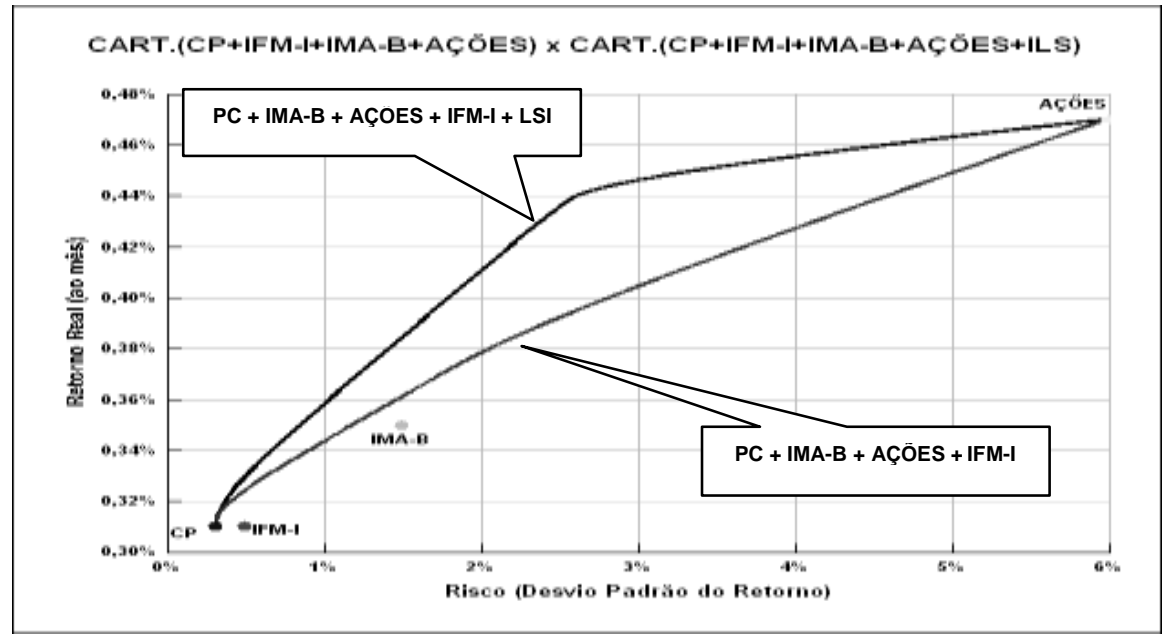

Figure 8 - Efficient frontier with inclusion of IFM-I + LSI - Scenario IV Source: Output from PortfolioWorks.

The inclusion of PE/VC in the basic portfolio caused a small shift in the efficient frontier, as shown in Figure 9 below.

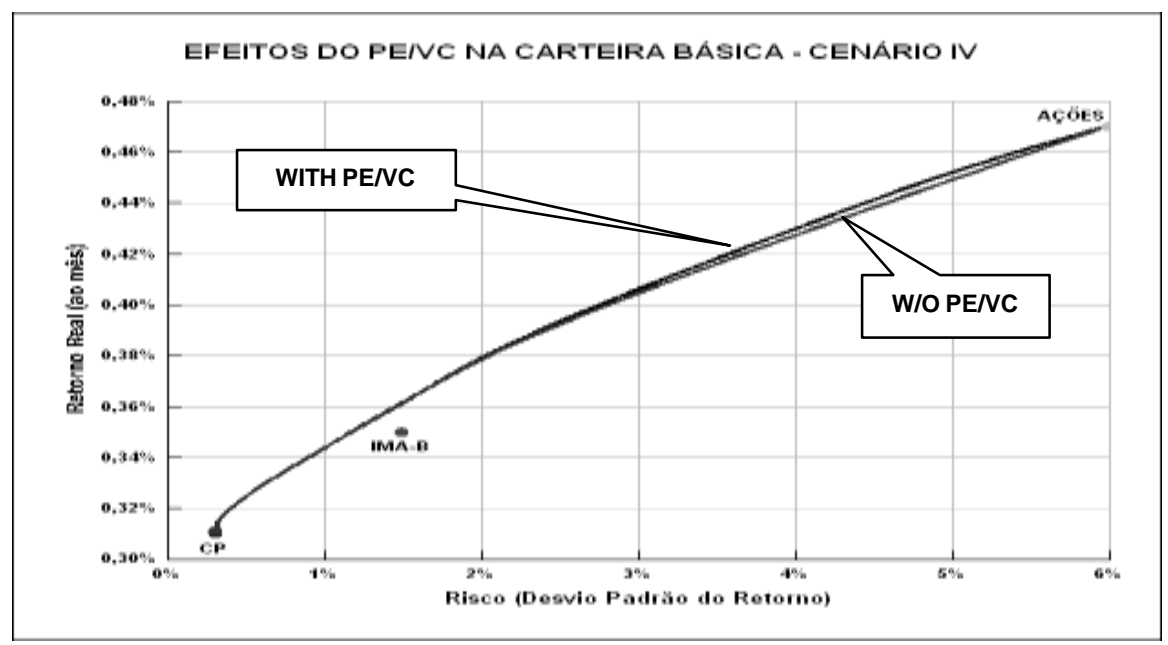

Figure 9 - Efficient frontier with inclusion of PE/VC - Scenario IV

Source: Output from PortfolioWorks. 
Despite the apparently small influence of PE/VC in Scenario IV, the analysis of the portfolio's composition shows the presence of $\mathrm{PE} / \mathrm{VC}$ in all the portfolios with expected real return greater than $0.33 \%$ per month. Of the 500 optimized portfolios, $\mathrm{PE} / \mathrm{VC}$ is present in 456. Therefore, although not causing a significant shift of the efficient frontier, PE/VC investments play an important role in the diversification of the assets.

A portfolio that does not contain adequate percentages of at least the assets IMA-B or IMA-C, Private Credit (represented in this study by the credit funds with returns published by the Brazilian Association of Investment Banks - ANBID) and Shares (Ibovespa) has low efficiency and a very limited return.

\subsection{DIVERSIFICATION WITH GLOBAL ASSETS}

To test the effects of diversification with international assets, we considered a basic portfolio composed of the domestic assets that aggregated the most efficiency, according to the results presented above. The results to this point were obtained without any restriction on the maximum limits for allocation. These restrictions are considered in Section 4.4.

Since for Scenario IV we assumed that the global assets would have the same returns and volatilities as those of Scenario II, we performed the simulations only for Scenarios I and IV.

The figures below illustrate the effect of including the asset iShares MSCI Mexico Investable Market. A significant gain in the efficient frontier can be observed, both for the price expressed in dollars and in reais, considering Scenario 1.

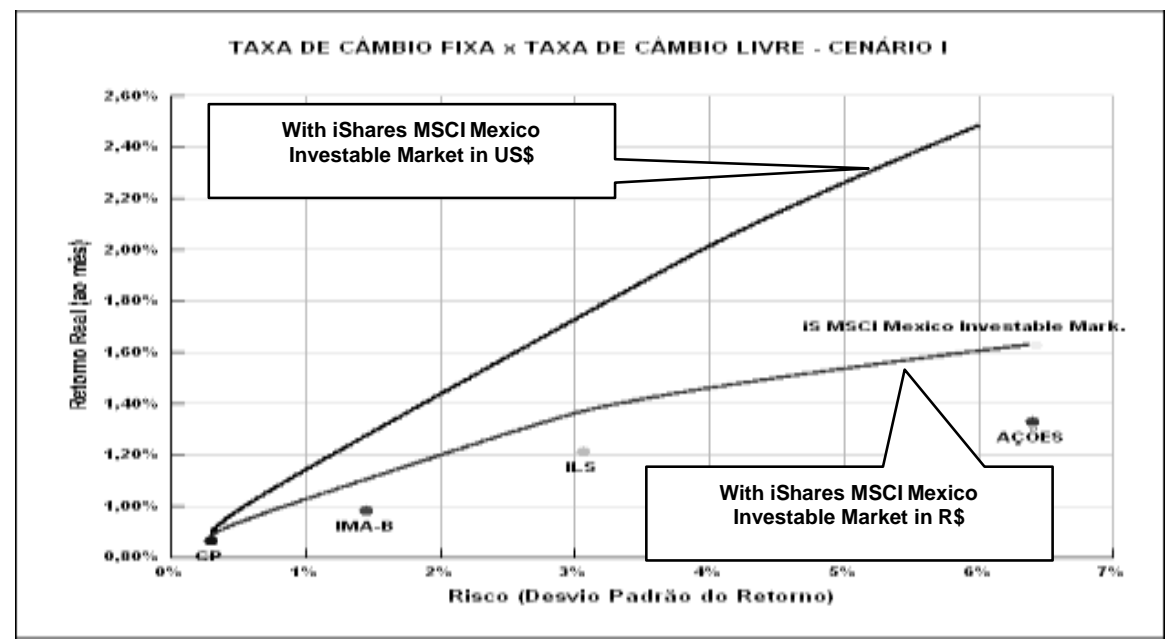

Figure 10 - Effects of the exchange rate - iShares MSCI Mexico Investable Market Source: Output from PortfolioWorks. 


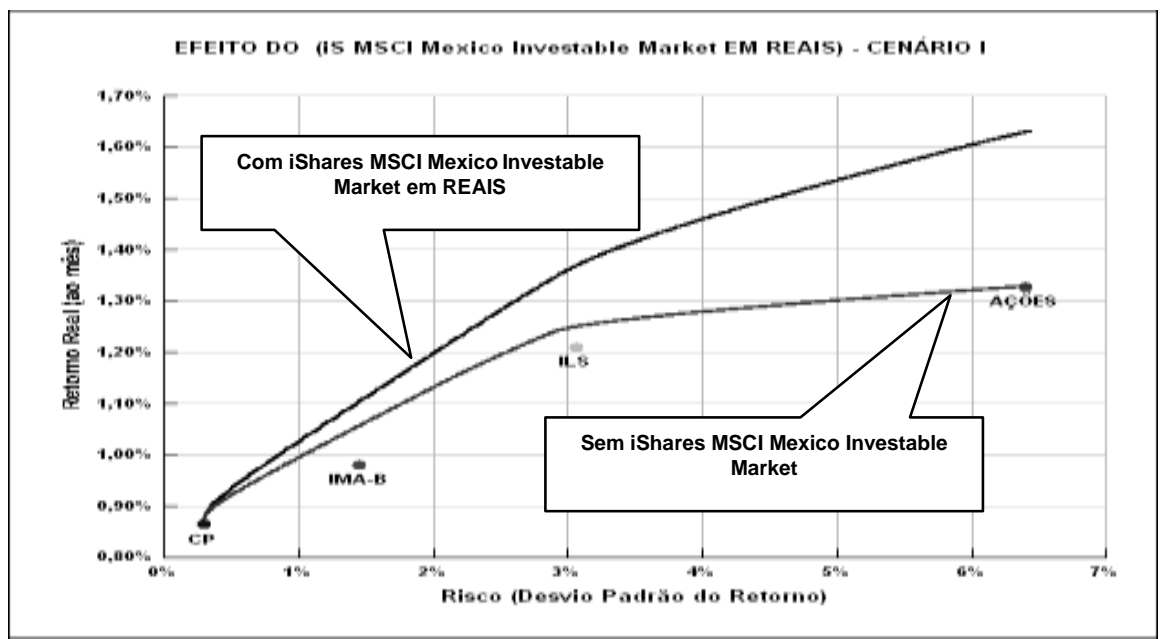

Figure 11 - Effects of the exchange rate - iShares MSCI Mexico Investable Market Source: Output from PortfolioWorks.

Table 8 below summarizes the results of the simulations for diversification with global assets, assuming a fixed and floating exchange rate in the two scenarios considered.

Table 8 - Allocation with fixed exchange rate $x$ floating exchange rate

\begin{tabular}{|c|c|c|c|c|}
\hline \multirow{3}{*}{ ASSETS } & \multicolumn{4}{|c|}{$\begin{array}{l}\text { DOES THE ASSET CONTRIBUTE TO EFFICIENT } \\
\text { ALLOCATION? }\end{array}$} \\
\hline & \multicolumn{2}{|c|}{ FIXED EXCHANGE RATE } & \multicolumn{2}{|c|}{$\begin{array}{l}\text { FLOATING EXCHANGE } \\
\text { RATE }\end{array}$} \\
\hline & $\begin{array}{c}\text { SCENARIO } \\
\text { I }\end{array}$ & $\begin{array}{l}\text { SCENARIO } \\
\text { IV }\end{array}$ & $\begin{array}{l}\text { SCENARIO } \\
\text { I }\end{array}$ & $\begin{array}{l}\text { SCENARIO } \\
\text { IV }\end{array}$ \\
\hline iShares MSCI Pacific ex-Japan & $\mathrm{NO}$ & YES & $\mathrm{NO}$ & NO \\
\hline iShares MSCI Emergent Markets & YES & YES & NO & YES \\
\hline iShares Dow Jones U.S Energy Sector & YES & YES & NO & YES \\
\hline iShares S\&P Latin America 40 & YES & YES & YES & YES \\
\hline iShares MSCI Mexico Investable Markets & YES & YES & YES & YES \\
\hline
\end{tabular}

Source: Prepared by the authors.

Table 9 contains a summary that illustrates the importance of foreign investments in Scenario IV. The simulated portfolios have the same risk as the one that hypothetically represents the allocation of Brazilian pension funds in December 2008. In Scenario IV, the return of this hypothetical portfolio is $0.33 \%$ per month ( $4.03 \%$ a year) for a risk of $1.16 \%$ (see Table 5). When adding the LSI, for this same risk, the return rises to $0.37 \%$ monthly (4.53\% yearly), as shown in Table 9 - portfolio 77, below. With the assets chosen for foreign investments, this return can reach $0.44 \%$ a month $(5.41 \%$ a year) for the same risk - portfolio 69 below.

The inclusion of private equity investments in the portfolio, represented by the Private Equity Index Europe - PRIVEX, in the case of a fixed exchange rate, would not aggregate value to the portfolio in Scenario II. However, in Scenario IV, despite the small change in the efficient frontier, that asset was present in 456 of the 500 simulated portfolios. 
Table 9 - Foreign Investments

\begin{tabular}{|c|c|c|c|c|c|c|c|}
\hline \multicolumn{8}{|c|}{ SCENARIO IV - FREE LIMITS - FLOATING EXCHANGE RATE } \\
\hline \multicolumn{6}{|c|}{ ALLOCATION } & \multirow[b]{2}{*}{$\begin{array}{l}\text { Risk equal to that of the } \\
\text { hypothetical portfolio }\end{array}$} & \multirow[b]{2}{*}{ Return } \\
\hline Portfolio & IMA-B & $\mathrm{PC}$ & Shares & LSI & $\begin{array}{l}\text { iShares Dow Jones } \\
\text { U.S Energy Sector }\end{array}$ & & \\
\hline 83 & $7.59 \%$ & $52.66 \%$ & $1.77 \%$ & $23.74 \%$ & $14.24 \%$ & $1.16 \%$ & $0.39 \%$ \\
\hline Portfolio & IMA-B & $\mathrm{PC}$ & Shares & LSI & $\begin{array}{l}\text { iShares MSCI Mexico } \\
\text { Investable Market }\end{array}$ & $\begin{array}{l}\text { Risk equal to that of the } \\
\text { hypothetical portfolio }\end{array}$ & Return \\
\hline 69 & $0.00 \%$ & $72.35 \%$ & $0.47 \%$ & $11.92 \%$ & $15.26 \%$ & $1.16 \%$ & $0.44 \%$ \\
\hline Portfolio & IMA-B & $\mathrm{PC}$ & Shares & LSI & No foreign investment & $\begin{array}{l}\text { Risk equal to that of the } \\
\text { hypothetical portfolio }\end{array}$ & Return \\
\hline 77 & $12.69 \%$ & $46.56 \%$ & $8.19 \%$ & $32.56 \%$ & $0.00 \%$ & $1.16 \%$ & $0.37 \%$ \\
\hline
\end{tabular}

Source: Prepared by the authors.

Considering the exchange traded funds of the iShares family managed by Barclays Global Investors (BGI), which represent assets in various sectors of the global economy, the diversification of portfolios with foreign investments (if permitted for Brazilian pension funds), represented by iShares, would improve the portfolios' efficiency, especially in Scenario IV.

For the risk level of the hypothetical portfolio (1.16\%) in Scenario IV, considering diversification with all the domestic and global alternative assets, the portfolio's expected real return varies, depending on the foreign asset considered, rising by 0.39 to 0.44 percentage point a month or 4.78 to 5.41 percentage points a year. This shows that foreign investments can enhance the efficiency of the portfolios of Brazilian pension funds.

\subsection{THE IMPLICATIONS OF THE ALLOCATION LIMITS}

\subsubsection{Allocation without imposition of limits}

The results presented in Table 10 below show the allocation of assets in Scenario III, which includes the historical series of returns for 2008 when asset prices were negatively affected by the global financial crisis. In this scenario, as expected, the allocation in variable income would be zero, except in portfolios 1 to 3, with negligible portions.

Table 10 - Portfolios optimized without the imposition of limits - Scenario III (in \%)

\begin{tabular}{ccccccccccccc}
\hline \multicolumn{10}{c}{ SCENARIO III - 2004-2008 HISTORICALSERIES } \\
\hline \multirow{2}{*}{ Portfolios } & IRFM & $\begin{array}{c}\text { IMA- } \\
\text { B }\end{array}$ & $\begin{array}{c}\text { IMA- } \\
\text { B }\end{array}$ & $\begin{array}{c}\text { IMA- } \\
\text { B }\end{array}$ & PC & Shares & PE/VC & \multicolumn{2}{c}{ Real } \\
Estate & Loans/Financing & Risk Return \\
\hline 1 & 0.00 & 0.34 & 0.00 & 8.99 & 12.25 & 0.18 & 0.00 & 23.97 & 54.27 & 0.18 & 0.50 \\
3 & 0.00 & 0.00 & 1.46 & 7.93 & 19.87 & 0.03 & 0.00 & 18.23 & 52.47 & 0.18 & 0.54 \\
14 & 0.00 & 0.00 & 4.19 & 6.36 & 31.21 & 0.00 & 0.00 & 8.44 & 49.80 & 0.21 & 0.61 \\
48 & 0.00 & 0.00 & 9.20 & 8.02 & 66.84 & 0.00 & 0.00 & 0.00 & 15.94 & 0.29 & 0.72 \\
149 & 0.00 & 0.00 & 33.19 & 56.05 & 10.76 & 0.00 & 0.00 & 0.00 & 0.00 & 0.53 & 0.80 \\
170 & 0.00 & 0.00 & 36.97 & 63.03 & 0.00 & 0.00 & 0.00 & 0.00 & 0.00 & 0.59 & 0.81 \\
345 & 9.52 & 0.00 & 70.50 & 19.99 & 0.00 & 0.00 & 0.00 & 0.00 & 0.00 & 1.01 & 0.89 \\
500 & 0.00 & 0.00 & 100.00 & 0.00 & 0.00 & 0.00 & 0.00 & 0.00 & 0.00 & 1.38 & 0.95 \\
\hline
\end{tabular}

Source: Prepared by the authors with output data from PortfolioWorks. 
Scenario IV, whose allocation results are shown in Table 11 below, is the scenario of economic stability with real interest rates around $4 \%$ a year. The real return for the portfolio with the highest risk in this scenario is $5.79 \%$ a year, with $100 \%$ invested in variable income securities.

Table 11 - Portfolios optimized without imposition of limits -Scenario IV

\begin{tabular}{|c|c|c|c|c|c|c|c|c|c|c|c|}
\hline \multicolumn{12}{|c|}{ SCENARIO IV - ECONOMIC STABILITY WITH RISK OF THE 2004-2007 HISTORICAL SERIES } \\
\hline Portfolios & IRFM & $\begin{array}{l}\text { IMA- } \\
\text { B }\end{array}$ & $\begin{array}{l}\text { IMA- } \\
\text { C }\end{array}$ & $\begin{array}{l}\text { IMA- } \\
\mathbf{S}\end{array}$ & PC & Shares & PE/VC & $\begin{array}{l}\text { Real } \\
\text { Estate }\end{array}$ & $\begin{array}{c}\text { EMPREST } \\
\text { /FINANC. }\end{array}$ & Risk & Return \\
\hline 1 & 0.00 & 0.92 & 0.92 & 0.00 & 49.97 & 0.20 & 0.00 & 28.38 & 19.62 & 0.19 & 0.21 \\
\hline 5 & 0.00 & 0.00 & 5.20 & 0.00 & 86.39 & 0.17 & 0.00 & 8.24 & 0.00 & 0.24 & 0.28 \\
\hline 6 & 0.00 & 0.00 & 5.64 & 0.00 & 89.27 & 0.16 & 0.00 & 4.93 & 0.00 & 0.25 & 0.29 \\
\hline 8 & 0.00 & 1.26 & 4.39 & 0.00 & 93.92 & 0.42 & 0.00 & 0.00 & 0.00 & 0.28 & 0.31 \\
\hline 14 & 8.71 & 9.69 & 0.00 & 0.00 & 80.04 & 1.56 & 0.00 & 0.00 & 0.00 & 0.35 & 0.32 \\
\hline 15 & 11.98 & 9.70 & 0.00 & 0.00 & 76.68 & 1.64 & 0.00 & 0.00 & 0.00 & 0.37 & 0.32 \\
\hline 49 & 80.07 & 14.32 & 0.00 & 0.00 & 0.00 & 4.54 & 1.07 & 0.00 & 0.00 & 0.79 & 0.34 \\
\hline 58 & 70.97 & 20.25 & 0.00 & 0.00 & 0.00 & 5.86 & 2.92 & 0.00 & 0.00 & 0.90 & 0.34 \\
\hline 69 & 60.80 & 26.87 & 0.00 & 0.00 & 0.00 & 7.34 & 4.99 & 0.00 & 0.00 & 1.04 & 0.35 \\
\hline 154 & 0.00 & 61.79 & 0.00 & 0.00 & 0.00 & 18.28 & 19.93 & 0.00 & 0.00 & 2.10 & 0.38 \\
\hline 183 & 0.00 & 49.99 & 0.00 & 0.00 & 0.00 & 23.58 & 26.44 & 0.00 & 0.00 & 2.46 & 0.39 \\
\hline 302 & 0.00 & 7.37 & 0.00 & 0.00 & 0.00 & 42.69 & 49.94 & 0.00 & 0.00 & 3.94 & 0.43 \\
\hline 303 & 0.00 & 7.03 & 0.00 & 0.00 & 0.00 & 42.85 & 50.12 & 0.00 & 0.00 & 3.95 & 0.43 \\
\hline 334 & 0.00 & 0.00 & 0.00 & 0.00 & 0.00 & 49.93 & 50.07 & 0.00 & 0.00 & 4.34 & 0.43 \\
\hline 335 & 0.00 & 0.00 & 0.00 & 0.00 & 0.00 & 50.30 & 49.70 & 0.00 & 0.00 & 4.35 & 0.44 \\
\hline 499 & 0.00 & 0.00 & 0.00 & 0.00 & 0.00 & 99.73 & 0.27 & 0.00 & 0.00 & 6.39 & 0.47 \\
\hline 500 & 0.00 & 0.00 & 0.00 & 0.00 & 0.00 & 100.00 & 0.00 & 0.00 & 0.00 & 6.40 & 0.47 \\
\hline
\end{tabular}

Source: Prepared by the authors with output data from PortfolioWorks.

Analysis of the results with the portfolios optimized without the imposition of limits leads to the following findings and respective comments:

a. In all the scenarios the limits were violated for low-risk portfolios. In this case, the allocation would have to occur with higher risk, irrespective of the needs established in the investment policy of the particular benefit plan.

b. Except for Scenario III, in all the others the risk limits for variable income were violated for higher risk portfolios. This fact shows that - considering only Scenarios I and II the determination of the regulator establishing maximum allocation limits is correct, since the returns at the intermediate risk levels are more than sufficient to exceed the actuarial target of $6 \%$ a year, as mentioned previously. However, considering Scenario IV, it would be impossible to achieve optimal allocation only with domestic assets and with real return above $0.39 \%$ a month $(4.78 \%$ a year), without violating the limit of $50 \%$ in variable income, as indicated in portfolio 183 of Table 11. 


\subsubsection{Allocation with imposition of maximum limits}

To assess the possible restrictions to the process of optimizing the portfolios because of the maximum limits established by the regulator, we simulated efficient frontiers considering allocation with and without those maximum limits.

Table 12 - The limits increase the risk - domestic assets - SCENARIOII

\begin{tabular}{|c|c|c|c|c|c|c|c|}
\hline \multicolumn{8}{|c|}{ SCENARIO II - LIMITS $x$ RISK } \\
\hline Portfolios & $\mathbf{P C}$ & Shares & IMA-B & IFM-I & LSI & Risk & Return \\
\hline \multicolumn{8}{|c|}{ PORTFOLIOS OPTIMIZED WITHOUT IMPOSITION OF LIMITS } \\
\hline 1 & $96.43 \%$ & $0.03 \%$ & $2.30 \%$ & $0.00 \%$ & $1.24 \%$ & $0.30 \%$ & $0.80 \%$ \\
\hline 3 & $90.64 \%$ & $1.56 \%$ & $4.43 \%$ & $0.00 \%$ & $3.37 \%$ & $0.32 \%$ & $0.82 \%$ \\
\hline 4 & $89.27 \%$ & $1.93 \%$ & $4.93 \%$ & $0.00 \%$ & $3.87 \%$ & $0.33 \%$ & $0.83 \%$ \\
\hline 5 & $88.08 \%$ & $2.24 \%$ & $5.37 \%$ & $0.00 \%$ & $4.31 \%$ & $0.35 \%$ & $0.83 \%$ \\
\hline 25 & $72.63 \%$ & $6.34 \%$ & $11.04 \%$ & $0.00 \%$ & $9.98 \%$ & $0.57 \%$ & $0.89 \%$ \\
\hline 26 & $71.98 \%$ & $6.51 \%$ & $11.28 \%$ & $0.00 \%$ & $10.22 \%$ & $0.58 \%$ & $0.90 \%$ \\
\hline 27 & $71.34 \%$ & $6.69 \%$ & $11.52 \%$ & $0.00 \%$ & $10.45 \%$ & $0.60 \%$ & $0.90 \%$ \\
\hline 28 & $70.70 \%$ & $6.86 \%$ & $11.76 \%$ & $0.00 \%$ & $10.69 \%$ & $0.61 \%$ & $0.90 \%$ \\
\hline 29 & $70.07 \%$ & $7.02 \%$ & $11.99 \%$ & $0.00 \%$ & $10.92 \%$ & $0.62 \%$ & $0.90 \%$ \\
\hline 30 & $69.43 \%$ & $7.19 \%$ & $12.22 \%$ & $0.00 \%$ & $11.15 \%$ & $0.63 \%$ & $0.91 \%$ \\
\hline 99 & $29.03 \%$ & $17.91 \%$ & $27.07 \%$ & $0.00 \%$ & $25.99 \%$ & $1.42 \%$ & $1.07 \%$ \\
\hline 262 & $0.00 \%$ & $49.91 \%$ & $0.44 \%$ & $0.00 \%$ & $49.65 \%$ & $3.27 \%$ & $1.40 \%$ \\
\hline \multicolumn{8}{|c|}{$\begin{array}{l}\text { PORTFOLIO WITH LIMITS OF CMN RES. } 3,456 \text { : PC }<=20 \% \text {; Shares }<= \\
50 \% \text {; LSI }<=3 \%\end{array}$} \\
\hline 1 & $20.00 \%$ & $0.00 \%$ & $0.00 \%$ & $80.00 \%$ & $0.00 \%$ & $0.43 \%$ & $0.81 \%$ \\
\hline 5 & $19.48 \%$ & $1.30 \%$ & $0.60 \%$ & $78.62 \%$ & $0.00 \%$ & $0.45 \%$ & $0.82 \%$ \\
\hline 64 & $16.53 \%$ & $8.68 \%$ & $13.72 \%$ & $61.07 \%$ & $0.00 \%$ & $0.78 \%$ & $0.90 \%$ \\
\hline 214 & $0.49 \%$ & $21.99 \%$ & $36.12 \%$ & $39.79 \%$ & $1.61 \%$ & $1.63 \%$ & $1.06 \%$ \\
\hline 215 & $0.26 \%$ & $22.07 \%$ & $36.24 \%$ & $39.79 \%$ & $1.64 \%$ & $1.63 \%$ & $1.06 \%$ \\
\hline 217 & $0.00 \%$ & $22.24 \%$ & $36.52 \%$ & $39.57 \%$ & $1.67 \%$ & $1.64 \%$ & $1.07 \%$ \\
\hline 218 & $0.00 \%$ & $22.33 \%$ & $36.69 \%$ & $39.32 \%$ & $1.66 \%$ & $1.65 \%$ & $1.07 \%$ \\
\hline 219 & $0.00 \%$ & $22.42 \%$ & $36.85 \%$ & $39.07 \%$ & $1.65 \%$ & $1.65 \%$ & $1.07 \%$ \\
\hline 222 & $0.00 \%$ & $22.69 \%$ & $37.34 \%$ & $38.33 \%$ & $1.64 \%$ & $1.67 \%$ & $1.07 \%$ \\
\hline 234 & $0.00 \%$ & $23.75 \%$ & $39.32 \%$ & $35.35 \%$ & $1.57 \%$ & $1.74 \%$ & $1.08 \%$ \\
\hline 500 & $0.00 \%$ & $50.00 \%$ & $50.00 \%$ & $0.00 \%$ & $0.00 \%$ & $3.23 \%$ & $1.34 \%$ \\
\hline
\end{tabular}

Table 12 below presents the results of allocation only in domestic assets. According to the table, the return-risk ordered pair of portfolio 64 (with limits) is $(0.90,0.78)$ and that of portfolio 26 (without limits) is $(0.90,0.58)$. The ordered pair of portfolio 217 (with limits) is $(1.07,1.64)$ while that of portfolio 99 (without limits) is $(1.07,1.42)$. Thus, in the two situations, the imposition of limits caused an increase in risk for the same returns.

With the imposition of limits, the maximum percentage of resources allocated to longshort funds (LSI) was $1.67 \%$, while the upper limit determined by the regulator for this type of asset is $3 \%$. 
Considering the allocation with global assets having the highest risk among those considered in this study, again with prices given in reais, the simulations show lower efficiency when the limits are imposed.

Table 13 below presents the results for Scenario I. With the limits, portfolio 1, which has the lowest risk with ordered pair $(0.96,1.16)$, has a higher risk than that of portfolio 70 , with $10.36 \%$ allocated to foreign assets and an ordered pair of $(1.05,1.13)$.

Table 13 - The limits increase the risk - investment abroad -Scenario I

\begin{tabular}{|c|c|c|c|c|c|c|c|}
\hline \multicolumn{8}{|c|}{ SCENARIO I - LIMITS x RISK } \\
\hline Portfolios & IMA-B & PC & Shares & LSI & $\begin{array}{c}\text { iS MSCI } \\
\text { Mexico } \\
\text { Investable } \\
\text { Mark (in } \\
\text { R\$) }\end{array}$ & Risk & Return \\
\hline \multicolumn{8}{|c|}{ OPTIMIZED PORTFOLIOS WITHOUT IMPOSITION OF LIMITS } \\
\hline 2 & $4.64 \%$ & $95.23 \%$ & $0.13 \%$ & $0.00 \%$ & $0.00 \%$ & $0.28 \%$ & $0.87 \%$ \\
\hline 3 & $7.36 \%$ & $90.32 \%$ & $0.70 \%$ & $0.59 \%$ & $1.03 \%$ & $0.31 \%$ & $0.89 \%$ \\
\hline 13 & $8.89 \%$ & $82.32 \%$ & $1.44 \%$ & $4.43 \%$ & $2.92 \%$ & $0.43 \%$ & $0.92 \%$ \\
\hline 14 & $9.01 \%$ & $81.66 \%$ & $1.50 \%$ & $4.75 \%$ & $3.08 \%$ & $0.44 \%$ & $0.92 \%$ \\
\hline 70 & $14.89 \%$ & $50.95 \%$ & $4.32 \%$ & $19.49 \%$ & $10.36 \%$ & $1.13 \%$ & $1.05 \%$ \\
\hline \multicolumn{8}{|c|}{ WITH LIMITS OF CMN RES. 3,456: PC $<=20 \%$; Shares $<=50 \%$; (LSI+EXT) $<=3 \%$} \\
\hline 1 & $80.00 \%$ & $20.00 \%$ & $0.00 \%$ & $0.00 \%$ & $0.00 \%$ & $1.16 \%$ & $0.96 \%$ \\
\hline 44 & $79.95 \%$ & $10.99 \%$ & $8.20 \%$ & $0.00 \%$ & $0.86 \%$ & $1.35 \%$ & $1.00 \%$ \\
\hline 45 & $80.17 \%$ & $10.70 \%$ & $8.23 \%$ & $0.00 \%$ & $0.90 \%$ & $1.36 \%$ & $1.00 \%$ \\
\hline 114 & $83.35 \%$ & $0.00 \%$ & $14.53 \%$ & $0.00 \%$ & $2.13 \%$ & $1.66 \%$ & $1.04 \%$ \\
\hline 115 & $83.21 \%$ & $0.00 \%$ & $14.67 \%$ & $0.00 \%$ & $2.12 \%$ & $1.67 \%$ & $1.05 \%$ \\
\hline 84 & $88.15 \%$ & $0.00 \%$ & $9.42 \%$ & $0.00 \%$ & $2.43 \%$ & $1.53 \%$ & $1.03 \%$ \\
\hline 179 & $76.04 \%$ & $0.00 \%$ & $22.30 \%$ & $0.00 \%$ & $1.66 \%$ & $1.95 \%$ & $1.07 \%$ \\
\hline 180 & $75.94 \%$ & $0.00 \%$ & $22.40 \%$ & $0.00 \%$ & $1.66 \%$ & $1.96 \%$ & $1.07 \%$ \\
\hline 467 & $52.44 \%$ & $0.00 \%$ & $47.41 \%$ & $0.00 \%$ & $0.16 \%$ & $3.23 \%$ & $1.15 \%$ \\
\hline 499 & $50.07 \%$ & $0.00 \%$ & $49.92 \%$ & $0.00 \%$ & $0.00 \%$ & $3.38 \%$ & $1.15 \%$ \\
\hline 500 & $50.00 \%$ & $0.00 \%$ & $50.00 \%$ & $0.00 \%$ & $0.00 \%$ & $3.38 \%$ & $1.15 \%$ \\
\hline
\end{tabular}

Source: Prepared by the authors with output data from PortfolioWorks.

\section{CONCLUSIONS}

The results of the simulations show that the imposition of allocation limits not only restricts the efficient frontier, but also shifts it to the right, implying increased risk for the same expected return or reduced return for the same expected risk.

This result was verified both with domestic and international assets. In a scenario with real interest rates of $4 \%$, the implications of imposing limits are more critical due to the low levels of return inherent to this scenario.

Finally, this study technically demonstrated a fact that has attracted much comment in the Brazilian pension fund industry and the specialized media, that in a scenario of economic stability and real interest rates below $6 \%$ a year, these funds' managers will have to find new 
investment alternatives. Among these alternatives are investment in the real sector of the economy through private equity/venture capital entities, investment in multimarket funds with more aggressive characteristics and also investment in foreign assets, as happens with pension funds in countries where real interest rates are at this level or even negative.

The present work evaluated the allocation of assets in static form, so as a suggestion for future works we recommend repeating this methodology in a setting with dynamic asset allocation, or imposing a budget constraint on reallocation of assets in the Markowitz model.

\section{REFERENCES}

ABRAPP - Associação Nacional das Entidades Fechadas de Previdência Complementar http://www.abrapp.org.br/apoio/estatisticas/internacional/fundosintl.ppt, accessed on January $15,2009$.

BACEN - Banco Central do Brasil http://www.bcb.gov.br/?FOCUS, accessed on April 9, 2010.

BGI - PortfolioWorks® User Guide, from Barclays Global Investors, 2009.

CAMBRIDGE ASSOCIATES LLC. U.S Private Equity Index and Benchmark Statistics, December 31, 2008, https://www.cambridgeassociates.com/pdf/Private\%20Equity\%20 Index.pdf, accessed on May 20, 2009.

CARDOSO, H. M. A avaliação de estratégias dinâmicas baseadas em risco na gestão de ativos de fundos de pensão no Brasil. Rio de Janeiro, 2009. MBA Dissertation - Faculdade de Administração e Finanças IBMEC, 2009.

CARMONA, C. U. M. Modelos de estimação da volatilidade. Recife, 2008. Notas de aula da disciplina Gerenciamento de Risk do mestrado profissionalizante em Economia da UFPE. Recife, 2008.

DAMIÃO, J. E. F. Comparação de carteiras otimizadas segundo o critério médiaVariância formadas através de estimativas robustas de risco e retorno. São Paulo, 2007. 36p. Master's Dissertation in Economics - Faculdade Ibmec São Paulo, São Paulo, 2007.

LAMM, Jr.; McFALL, R.; GHALEB-HARTER, T. Private Equity as an Asset Class: Its Role in Investment Portfolios. The Journal of Private Equity, Volume Fall 2001, number 8292, Institutional Investor Journals.

LOPES, A. B.; FURTADO, C. V. Private Equity na Portfolio de Investimentos das Entidades de Previdência Privada. Revista Contabilidade e Finanças. Especial Atuária. Universidade de São Paulo. São Paulo. pp. 108-126, 2006.

LORENZO FILHO, C. G.. Um panorama dos investimentos alternativos. In: $\mathbf{2 9}^{\circ}$

CONGRESSO BRASILEIRO DOS FUNDOS DE PENSÃO, 2008, Rio de Janeiro. Livro do Congresso. ABRAPP, ICSS, SINDAP, 2008. pp. 130-142.

MARKOWITZ, H.. Portfolio Selection. Journal of Finance, pp. 77-91, March 1952. USA.

PREVI - Caixa de Previdência dos Funcionários do Banco do Brasil, http://www.previ.com.br/quemsomos/relatorio2008/demonstrativo_investimentos.htm, accessed on August 4, 2009. 


\section{SAVOIA, J. R. LETÍCIA, L. N. B.. Efeitos da Internacionalização de Portfolios no} Mercado de Capitais Brasileiro. Faculdade de Economia e Administração - FEA. Universidade de São Paulo, São Paulo, 2007.

SHARPE, W. F. Capital Asset Prices: A Theory of Market Equilibrium under Conditions of Risk. The Journal of Finance, New York, vol XIX, 3 pp. 425-442, September 1964.

SPC - Secretaria da Previdência Complementa - Apresentação, XIV EPINNE - ENCONTRO DOS PROFISSIONAIS DE INVESTIMENTOS NORTE/NORDESTE, Porto de Galinhas, Pernambuco, May 2009.

- Informe Estatístico - December - 2008, Versão Preliminar

http://www.previdencia.gov.br/arquivos/office/3_090331-154413-999.pdf , accessed on August 5, 2009.

\footnotetext{
${ }^{\mathrm{i}}$ National Treasury Notes Indexed to Price Indices - NTN-B, with maturity on May 15, 2045.

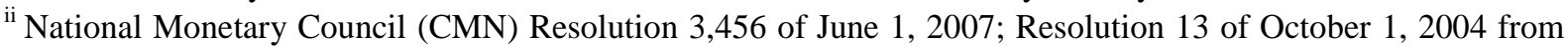
the National Complementary Social Security Management Council; Decree 4,942 of December 30, 2003, etc.

iii A company set up for the exclusive purpose of undertaking a determined project, with risks limited that project.

iv The PIBB traded on the BM\&FBovespa is an example of a Brazilian index-tracking fund. Recently BGI launched three index funds on the BM\&FBovespa: BOVA11 - tracking the Ibovespa, SMAL11 - tracking small cap stocks; and MILA11 - tracking midlarge cap stocks.

${ }^{v}$ A market information platform available over the Internet by signing a service provision agreement, carrying news and asset prices in the Brazilian and international market.

${ }^{v i}$ The target for the SELIC rate set by the Brazilian Central Bank's Monetary Policy Committee at its meeting of July 22, 2007 was $8.75 \%$ a year.

vii Investments in alternative assets are considered to be those in the real estate market, private equity/venture capital, multi-market funds, corporate credit and investments abroad, among others.

viii The "actuarial target" is the interest rate utilized in actuarial evaluation to obtain the present value of the reserves necessary to meet the obligations of a pension plan to pay benefits to its members. Thus the minimum yield of the investments should not be lower than the "actuarial target".
} 